\title{
La Ilustración a prueba de fuego. El incendio de la plaza Mayor de Madrid del 16 de agosto de 1790
}

\author{
ELISABEL LARRIBA \\ Université de Provence-umR Telemme \\ Miembro del Institut Universitaire de France
}

CES.XVIII, núm. 17 (2007), págs. 199-247. 
Resumen: El 16 de agosto de 1790 estalló en el Arco de la calle de Toledo un incendio que iba a destruir buena parte de la plaza Mayor de Madrid. En este artículo documentado en fuentes archivísticas y periodísticas se analiza la reacción que tuvieron ante el drama las autoridades (civiles y eclesiásticas) y el pueblo, así como la prensa que confirió al acontecimiento una resonancia nacional. Se examina también el estéril proceso de reflexión que se inició, a raíz de esa tragedia, en materia de prevención y de lucha contra el incendio.

Palabras clave: Ilustración. Incendio. Plaza Mayor de Madrid. Catástrofes. 


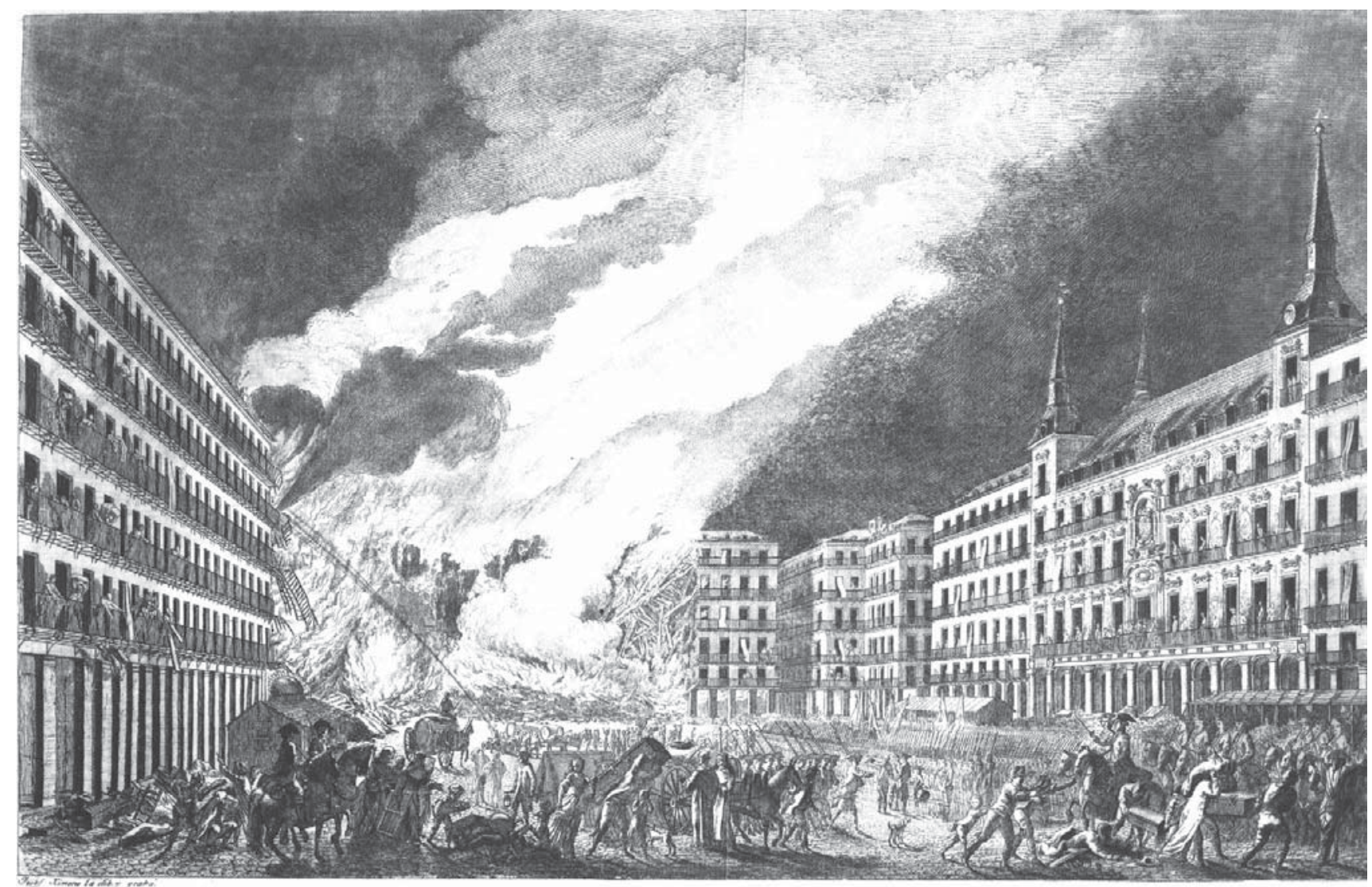

Plaza mayor de Madrid en la noche del día 16 de agosto de 1790, en que empezó el incendio y hasta donde se extendió en dicha noche

Biblioteca Nacional de España-Madrid (Inv. Est. núm. 14.871)

En la noche del 16 de agosto, como a hora de las 11, en el portal de paños, entre el arco de la calle de Toledo y la escalerilla de piedra que daba a los Cuchilleros, en el fondo de la habitación y tienda de un Mercader se manifestó un grande incendio ${ }^{1}$.

Así empezaba el imponente artículo que ese mismo mes de 1790 el Memorial literario dedicó al terrible fuego que con una rapidez deslumbrante se extendió por la plaza Mayor y sus inmediaciones, provocando el pánico entre el vecindario y causando en un instante la ruina de numerosas familias.

1 «Noticias del Incendio de la plaza Mayor de Madrid, que empezó en la noche del 16 de agosto», en Memorial literario, instructivo y curioso de la Corte de Madrid, agosto de 1790 (parte I), págs. 532-558, cita pág. 532. 


\section{Un impresionante y vano despliegue de fuerzas}

Como consta en el Memorial literario, pronto a poner de realce el celo de las autoridades, estas reaccionaron inmediatamente. Nada más dada la alerta, se personaron en la plaza Mayor para organizar la lucha contra el incendio el conde de Campomanes (gobernador del Consejo), Cristóbal de Zayas (gobernador de la Plaza) y Francisco Sabatini (arquitecto mayor de S. M.) «que sin apartarse de la Real Casa de la Panadería en toda la noche procuraban con el mayor desvelo cada uno por sus respectivos ramos evitar los horrorosos estragos de tan voraz incendio $»^{2}$. Pudieron contar con la ayuda de numerosos ingenieros, de varios arquitectos (entre los cuales Juan de Villanueva), de los alcaldes de corte y de barrio, del superintendente general de Policía, Mariano Colón, de los tenientes de la Villa, del corregidor, Joseph Antonio de Armona, etcétera. Se movilizó a toda la tropa que había en Madrid sin que ello fuera suficiente. Con lo cual en la madrugada vinieron de refuerzos las Reales Guardias Españolas y Walonas de Vicálvaro y Leganés. Se utilizaron todas las bombas, aguatochas y demás utensilios de que disponían en la capital los «matafuegos» ${ }^{3}$. Sin embargo, pese a los esfuerzos desplegados y a los cortes efectuados en las cuarenta y ocho primeras horas, el fuego se propagó con una increíble celeridad al encontrar al paso edificios que carecían de paredes divisorias de ladrillo o de piedra pero abundaban en madera. En unas pocas horas todo un lienzo de la plaza (el que iba del arco de la calle de Toledo al de la calle de Guadalajara) se derrumbó. Y fueron necesarios nueve días para extinguir el incendio, aunque el 25 de agosto todavía quedaban algunos sótanos en llamas y seguían declarándose pequeños fuegos entre los escombros de los edificios destruidos ${ }^{4}$. El balance era abrumador. Según el informe establecido el 11 de octubre de 1790 por el contador general de la Regalía del Real Hospedaje de Corte, Antonio de Armona, el número de casas «arruinadas, quemadas, y cortadas» ascendía a $52^{5}$ y 1302 personas quedaron desalojadas, como consta en el «Aviso al público» que se insertó en el Diario de Madrid del 25 de agosto de $1790^{6}$. En un santiamén todo lo perdieron, excepto la

2 Ibid., pág. 534.

Ibid., págs. 534-536.

Diario de Madrid, 26 de agosto de 1790 (núm. 238), pág. 957.

AHN, Consejos, leg. 3274. Informe remitido por Antonio de Armona al conde de Campomanes: Relación de todas las Casas que en la actualidad se hallan arruinadas así en la plaza Mayor, como en las inmediaciones de ella con motivo del Incendio acaecido en la Noche del 16 de Agosto de este presente año de 1790, con expresión de los Números con que estaban señaladas por la Real Regalía de Aposento, Dueños que las poseían, y terreno que cada una ocupaba según los Planes que existen en la Contaduría general de la misma Regalía, y vista ocular que ha hecho el Sr. Visitador general de ella, Madrid, 11 de octubre de 1790, 12 ff.

6 Diario de Madrid, 25 de agosto de 1790 (núm. 237), pág. 953: «[...] Que sin embargo de constar por listas muy exactas, que se han formado, el número de las personas que habitaban en las casas incendiadas, 
vida. Sorprendidos en su sueño, algunos ni siquiera tuvieron el tiempo de vestirse antes de arrojarse a la calle. Y, como subrayaban con emoción los redactores del Memorial literario,

[...] a pesar de tanto desvelo las más de las familias cercanas al principio del fuego no pudieron salvar sino sus personas, y aun no sus ropas para poder salir vestidos, y sin tener a donde ir a pasar la noche ni el resto de los días [...] A excepción de los pisos bajos que ocupaban los Mercaderes, todos los más habitantes eran de cortos haberes; por consiguiente, perdidas sus pocas alhajuelas, ropas, o muebles era inevitable quedar para siempre en el estado de la mayor infelicidad ${ }^{7}$.

\section{Un viento de solidaridad sopla por Madrid}

\section{II.1. Un objetivo prioritario para las autoridades: proporcionar el hospedaje y el alimento a las víctimas}

Ante la magnitud del desastre provocado por el incendio, las autoridades se apresuraron a tomar medidas para socorrer a las víctimas del siniestro. Como subrayó don Alejandro Vallejo (procurador Síndico General) en una representación expuesta ante el Ayuntamiento de la Villa el 17 de agosto ${ }^{8}$, cabía reaccionar inmediatamente ante «el sumo abandono, desnudez y falta de habitaciones donde puedan recogerse las muchas criaturas e hijos tiernos que andan vagos por las calles por efectos del presente lastimoso y formidable incendio». Procedía cuanto antes, subrayaba, ofrecer a esas míseras familias «receptáculo y abrigo» para evitarles los «riesgos y ofensas que de lo contrario experimentarían dispersas por calles, plazas y portales con horror de la humanidad y ofensa de ambas Majestades». Entre sus propuestas figuraba el abrir a las víctimas del incendio las puertas y habitaciones de la antigua casa de los jesuitas sita en la calle de la Concepción así como las de la Casa del Salvador de la calle Ancha de San Bernardo (trasladando los sacerdotes que la habitaban a otra casa de congregación o comunidad religiosa) y que se repartieran las familias más pobres entre los vecinos de Madrid que ofrecieran condiciones para ello.

\footnotetext{
que asciende al de 1302, deberán expresar todos los que quieran ser socorridos, el número individual de su familia, en la relación y noticias que van expresadas y les está mandado presentar; en la inteligencia de que para evitar fraudes, se cotejarán estas relaciones con las expresadas listas, como se ha anunciado en el aviso anterior $[\ldots] »$.

7 «Noticias del Incendio de la plaza Mayor de Madrid, que empezó en la noche del 16 de agosto», en Memorial literario, op. cit., pág. 536.

8 Archivo de la Villa de Madrid (AVm), Libro de Acuerdos núm. 220, Junta de Ayuntamiento del 17 de agosto de 1790, ff. 161-162.
} 
Deseando dar el ejemplo para que «se moviera y avivara la caridad pública» se declaraba dispuesto a acoger en su propia casa a un matrimonio de reducida familia.

Ese mismo día 17 de agosto, a petición del rey, se celebró una junta extraordinaria de gobierno en la Posada del conde de Campomanes en que se examinaron los medios de proporcionar a las víctimas del siniestro el hospedaje y alimento necesario a su subsistencia ${ }^{9}$. Se dictaminó que cuantos gozaran de recursos suficientes serían prioritarios en los mesones, paradores, así como en las posadas públicas y secretas «sin permitir que se alter[asen], ni al[zasen] de ningún modo los precios». Para los «menos pudientes o desvalidos» se acudiría provisionalmente a la hospitalidad de los claustros de las comunidades religiosas más cercanas de la plaza Mayor como San Felipe de Neri, San Felipe el Real, la Trinidad, Santo Tomás, San Martín, la Casa de la Misericordia, el Hospital de la Latina (para los matrimonios) y los Patios de las Descalzas Reales para las mujeres, instando dichas instituciones a proporcionar a cuantos se les destinasen comida por una duración de tres días, mientras, con la ayuda de las autoridades y de los «vecinos honrados», hallaran el medio de ganar su jornal. Y tras la junta que celebraron al día siguiente, se publicó un edicto (ampliamente difundido por vía de prensa y bajo forma de carteles, con una tirada de cien ejemplares ${ }^{10}$ ) en el cual el Consejo dio a conocer al vecindario que los alcaldes Ignacio Luis de Aguirre y Marqués de Casa García Postigo (domiciliados respectivamente en la calle del Carmen y en la de la Magdalena) atenderían a las personas que hubieran perdido su casa, especificando se ofrecería a los más miserables y por ocho días no sólo el hospedaje sino también el alimento $^{11}$.

9 ahn, Consejos, leg. 3274. Acuerdos de los Sres. de Gobierno en la Posada de S. E. Madrid 17 de agosto de 1790, $5 \mathrm{ff}$.

10 Ahn, Consejos, leg. 3274. Nota de Jerónimo Velarde y Sola a Pedro Escolano de Arrieta, Madrid, 18 de agosto de 1790.

11 Cartel reproducido en el Diario de Madrid del 19 de agosto de 1790 (núm. 231), págs. 925-926: «CARTEL. Cumpliendo el Consejo con los encargos hechos por S. M. para atender el socorro de los vecinos que han padecido la desgracia del Incendio que principió en la plaza Mayor a las 11 de la noche del día 16 de este mes, ha tomado con su Real noticia y aprobación, las providencias conducentes a este piadoso objeto, y ha comunicado para su ejecución a la Sala, por lo que se hace saber a todos los vecinos y personas que han experimentado dicha desgracia, se presenten a los Sres. Alcaldes D. Ignacio Luís de Aguirre, y Marqués de Casa García Postigo, que viven el primero en la calle del Carmen, casa inmediata a la Carbonería, y el segundo en la de la Magdalena, frente de la fuente de los Relatores, casa de la Cadena, por quienes se dará a todos la disposición correspondiente para su hospedaje; y a los menos pudientes y miserables, no sólo el hospedaje, sino también el alimento necesario por término de 8 días. Ya para que llegue a noticia del Público, se hace saber por medio de este edicto, del cual se fijan ejemplares en los sitios acostumbrados de la Corte, y autorizados de D. Joaquín Gómez Palacio, Escribano de Cámara y de Gobierno de Sala. Madrid 18 de agosto de $1790 »$. 


\section{II.2. El carácter ejemplar de la generosidad regia}

La familia real, conmovida por lo acontecido, quiso contribuir personalmente y de manera significativa a los gastos sufragados. Carlos IV, deseoso de afirmarse como padre de su pueblo, de marcar su apoyo moral y económico a súbditos sumidos en el dolor y la desesperanza, abrió el paso el 18 de agosto con un esplendoroso donativo de un millón de reales, invitando los demás miembros de la familia real a seguir sus pisadas. A los dos días, el 20 de agosto, la reina María Luisa participó a su vez con 200 mil reales, el Príncipe de Asturias lo mismo hizo con 100 mil reales y otros tantos fueron donados en nombre del infante don Carlos así como de las infantas María Amalia, María Luisa y María Isabel. Finalmente el 28 de agosto y el 19 de septiembre los infantes don Antonio y don Pedro contribuyeron respectivamente con 50 mil y 100 mil reales. La familia real proporcionó pues en totalidad nada menos que 1.550.000 reales $^{12}$, o sea el equivalente de la renta anual del arzobispado de Santiago, uno de los más ricos de España ${ }^{13}$. Tamaña generosidad no pasó desapercibida y la prensa contribuyó a que quedara pública constancia de ello, para mayor gloria de la institución monárquica. Los redactores del Memorial literario, por ejemplo, tras evocar, en el número de agosto, el triste estado en que se hallaban las víctimas del incendio, no omitieron hacer referencia a dichos donativos:

Nuestro piadoso y benigno Soberano el Rey D. Carlos IV, cuya razón nunca se aparta de la compasión del pobre, entre los cuidados y los desvelos del incendio, destinó inmediatamente con su innata generosidad la cantidad de un millón de rs. vn. para dar de comer, y para socorro de estos pobres afligidos, cuyo ejemplo siguió la caritativa Reina Nuestra Señora, D. ${ }^{a}$ Luisa su Esposa, y con ella toda la Real familia, contribuyendo con cuatro cientos y cincuenta mil rs. vn. al mismo efecto. Todo lo cual fue comunicado al Excmo. Sr. D. Pedro López de Lerena, Consejero y secretario de Estado del Despacho de Hacienda, con Orden Real de que lo distribuyese con atención a las circunstancias de las personas y pérdidas, con aquella equidad y justicia que tiene acreditada ${ }^{14}$.

12 AHN, Consejos, leg. 3274: Limosna dispensada por los Reyes Nuestros Señores y demás familia, para socorro de los que padecieron con motivo del Incendio ocurrido en la noche del 16 de Agosto, Madrid, 30 de septiembre de 1790 (1 f.) y, por lo que se refiere al donativo del Príncipe de Asturias, AGP, RF7, caja 140, exp. 19.

13 Maximiliano Barrio Gozalo, Sociedad, Iglesia y vida religiosa en la España del siglo XVIII. Notas para un estudio monográfico económico-político, Roma, Instituto Español de Historia Eclesiástica, 1989, pág. 301: renta media anual de la mitra de Santiago entre 1750 y 1799, 1.556 .578 reales.

14 «Noticias del Incendio de la plaza Mayor de Madrid, que empezó en la noche del 16 de agosto», en Memorial literario, op. cit., págs. 536-537. 
Lo mismo hizo el Diario de Madrid el $20^{15}$ y 21 de agosto ${ }^{16}$, precisando a la par que ello se anunciaba al público

[...] para la común satisfacción, y que en todos en debida gratitud, dirijan sus votos al Omnipotente, por la conservación de la preciosa salud de SS. MM., del Príncipe nuestro Señor, y de toda la Augusta familia, que incesantemente está derramando sobre esta gloriosa y dilatada Monarquía, las pruebas más relevantes de piedad y beneficencia ${ }^{17}$.

La actitud de la familia real, modélica y unida frente al sufrimiento de su pueblo, había también de inducir a los madrileños a mostrarse caritativos.

\section{II.3. La solidaridad de los madrileños \\ Como recalcaron los editores del Memorial literario en septiembre de 1790 :}

Ninguno hay tan insensible que pueda considerar sin estremecerse las tristes desgracias que vimos padecer poco hace a los habitantes de la plaza Mayor comprendidos en el incendio; ni ninguno que no agradezca la noble actividad de los que se emplearon en detener la rapidez de las llamas, en salvar de ellas a los infelices, y a sus haciendas. Pero todavía se venera con mayor gratitud y respeto la mano generosa de aquellos que sostenían con su liberalidad a los que trabajaban en esta empresa tan agradable a la humanidad, y al mismo tiempo socorrían las desgracias de aquellos a quienes las llamas hicieron miserables ${ }^{18}$.

15 «Noticia del Incendio de la plaza Mayor», en Diario de Madrid, 20 de agosto de 1790 (núm. 232), pág. 928: «El piadoso corazón de S. M. ha dispensado a favor de los habitantes de las casas incendiadas, de su Real Erario un millón de rs. para que se distribuya entre estas familias, confiando este encargo al Excmo. Sr. Conde de Campomanes, gobernador del Consejo, atendiendo a la magnitud, número, y demás calidad de estos vecinos, sin perjuicio de la demanda general acordada por el Consejo, con Real noticia y aprobación e iguales objetos, habiéndoselo comunicado este generoso socorro de S. M. por el Excmo. Sr. D. Pedro López de Lerena, con fecha del 18 del corriente».

16 «Continuación de las noticias del Incendio», en Diario de Madrid, 21 de agosto de 1790 (núm. 233), pág. 931: «Imitando la Reina nuestra Señora, el generoso, y caritativo celo del Rey, su amado Esposo, ha mandado poner a disposición del Excmo. Sr. Conde de Campomanes, Gobernador del Consejo, para que pueda atender en los términos que le están encargados al socorro de las familias reducidas a la miseria por el incendio, la cantidad de cuatrocientos mil reales vellón, en esta forma: doscientos mil reales a nombre de S. M.; cien mil a nombre del Príncipe nuestro Señor, y los cien mil restantes a nombre del Señor Infante Carlos, y las Señoras Infantas Doña María Amalia, Doña María Luisa, y Doña María Isabel».

17 Ibid., pág. 932.

18 «Muestra de la beneficiencia del Excelentísimo Señor Duque de Medinaceli y de Santisteban, en el socorro del incendio de la plaza Mayor de Madrid la noche del 16 de Agosto», en Memorial literario, septiembre de 1790 (parte II), págs. 149-150. 
De hecho, varios particulares quisieron también manifestar económicamente su solidaridad para con las víctimas. Entre ellos figuraba y destacaba el duque de Medinaceli y Santistebán.

Persuadido íntimamente de que la propiedad de las riquezas no podía tener lugar cuando se presentaban a sus ojos innumerables hermanos suyos, víctimas inocentes del fuego, destituidos de amparo y de sustento, que reclamaban los derechos de la humanidad y de la naturaleza, abandonó una porción de sus bienes sacrificándola al bien de sus conciudadanos con aquel placer inocente que sólo se deja gustar de las almas virtuosas y compasivas ${ }^{19}$.

Tomó inmediatamente varias medidas para aliviar no sólo a las familias afectadas por la catástrofe sino también a cuantos luchaban por detener el fuego. Desembolsó algo más de 15.000 reales para que durante ocho días (del 19 al 26 de agosto inclusive) se diese a trescientos pobres, comida, cena, almuerzo y cama en los conventos del Carmen Calzado y de la Victoria. Premió, por el mismo plazo, con cuatro reales diarios a cada uno de los soldados que participaron en la extinción del incendio, lo que supuso un gasto de 50.652 reales. Asimismo, al haberse trasladado a la plaza (desde su capilla del Convento de Trinitarios Descalzos) la efigie de Jesús de nazareno y construido un altar bajo el Arco de la Real Casa de la Panadería para celebrar misas en la misma plaza, el duque ofreció (entre otras cosas, y por un monto de 35.650 reales) desayuno, comida, refresco, cena y limosna a los asistentes al culto, a los trabajadores de la plaza y a cuantos se presentaron. El caritativo y generoso duque de Medinaceli contribuyó pues en total con algo más de 100.500 reales. Ninguno de los infantes llegó a tanto. Con lo cual los redactores del Memorial literario (que dedicaron varios artículos a la catástrofe) no dudaron en rendir un fervoroso homenaje a este excelso representante de la alta nobleza que no se olvidaba de los deberes inherentes a su clase y dieron pues a conocer con sobrados detalles esta "acción tan generosa y compasiva» ${ }^{20}$ que bien merecía ser aplaudida por todos y constituía una magnífica lección sobre el modo de socorrer a los pobres.

La reacción de Alfonso Garrido, dorador de las Reales Caballerías, también fue inmediata. El 17 de agosto puso a disposición del Consejo 30.000 reales para «alivio de las muchas familias que habían quedado reducidas a la miseria

\footnotetext{
$19 \quad$ Ibid., págs. 150-151.

20 Ibid., pág. 152: «Por tanto nuestro reconocimiento nos obliga a publicar esta acción tan generosa y compasiva del Excmo. Señor Duque de Medinaceli y Santistebán, para que aplaudiéndola todos, aprendan a socorrer a los pobres».
} 
Producto de la colecta general por barrios (clasificación en función del importe de los donativos)

\begin{tabular}{|c|c|c|}
\hline Cuartel & $\begin{array}{l}\text { Barrios (con indicación } \\
\text { del n. } .^{\circ} \text { de los barrios) }\end{array}$ & Responsable de la colecta \\
\hline Palacio & La Encarnación (15) y Doña María de Aragón (16) & Conde de Moctezuma \\
\hline San Jerónimo & La Cruz (43) y Las Monjas de Pinto (44) & Marqués de Villahermosa \\
\hline San Jerónimo & Buen Suceso (41) y Las Baronesas (42) & Marqués de Valdecarzana \\
\hline Plaza Mayor & San Justo (7) y Santo Tomás (8) & Conde de Miranda \\
\hline Las Maravillas & El Carmen Calzado (25) y San Basilio (26) & Conde de Carrión \\
\hline El Barquillo & Salesas (33) y Guardias Españolas (34) & Duque de Frias \\
\hline El Barquillo & Mercenarias Descalzas (39) San Luis (40) & Marqués de Iranda \\
\hline El Avapies & La Trinidad (53) y San Isidro Nuevo (54) & Conde de la Roca \\
\hline La plaza Mayor & Panadería (5) y Santa Cruz (6) & Marqués de Belgida \\
\hline Afligidos & Leganitos (17) y El Rosario (18) & Conde de Altamira \\
\hline La plaza Mayor & San Ginés (3) y Santiago (4) & Marqués de Montealegre \\
\hline Afligidos & Afligidos (23) y San Marcos (24) & Conde de Montijo \\
\hline Las Maravillas & San Ildefonso (27) y El Hospicio (28) & Duque de Alburqueque \\
\hline El Avapies & La Comadre (51) y Ave María (52) & Marqués de Perales \\
\hline Las Maravillas & San Placido (31) y Buenavista (32) & Marqués de Villanueva \\
\hline La plaza Mayor & Las Descalzas Reales (1) y Los Ángeles (2) & Marqués de Villena \\
\hline San Jerónimo & Las Trinitarias (45) y Jesús Nazareno (46) & Duque de Medinaceli \\
\hline Afligidos & Plazuela del Gato (19) y Las Niñas de Monterrey (20) & Marqués de Hermosilla \\
\hline Las Maravillas & Moriana (29) y Buenadicha (30) & Marqués de Villadarias \\
\hline Palacio & Puerta de Segovia (9) y El Sacramento (10) & Duque de Osuna \\
\hline Palacio & San Nicolás (11) y Santa María (12) & Marqués de Malpica \\
\hline San Francisco & Huerta de del Bayo (59) y San Francisco (60) & Martin Fajardo \\
\hline El Barquillo & Capuchinos de la Paciencia (37) y San Pascual (38) & Duque de San Carlos \\
\hline El Avapies & Hospital general (49) y San Isabel (50) & Marqués de Villa López \\
\hline El Barquillo & San Antonio (35) y Niñas de Leganés (36) & Conde de la Vega del Pozo \\
\hline Afligidos & Montserrat (21) y Cuartel de Guardias de Corps (22) & Duque de Abrantes \\
\hline San Francisco & La Latina (63) y El Humilladero (64) & Antonio Jaramillo \\
\hline San Jerónimo & El Amor de Dios (47) y Plazuela de San Juan (48) & Marqués de Santiago \\
\hline Palacio & San Juan (13) y Caños del Peral (14) & Marqués de Tolosa \\
\hline El Avapies & San Cayetano (55) y Colegio de las Niñas de la Paz (56) & Marqués de Portago \\
\hline San Francisco & Puerta de Toledo (57) y Mira al Río (58) & Lucas de San Juan \\
\hline San Francisco & Las Vistillas (61) y San Andrés (62) & Duque de Alba \\
\hline
\end{tabular}

Fuente: AHn, Consejos, leg. 3284. Limosna que ha producido la Qüesta general, y existe en el Arca de tres llaves colocada en el Convento de Santo Tomás, Madrid, 30 de septiembre de 1790; Censo de Floridablanca [Fernando Jiménez de Gregorio, La población de la actual provincia de Madrid en el Censo de Floridablanca (1786), Madrid, Diputación Provincial de Madrid, 1980, págs. 150-181]. 


\begin{tabular}{|c|c|c|}
\hline $\begin{array}{l}\text { Importe en } \\
\text { rs. de vn/mrs }\end{array}$ & $\begin{array}{l}\text { Número de habitantes } \\
\text { para cada binomio }\end{array}$ & $\begin{array}{l}\text { Donativo medio } \\
\text { (en rs.) per capita }\end{array}$ \\
\hline 71130 & $2926(1595+1331)$ & 24,3 \\
\hline 64999 & $4657(3060+1597)$ & 13,9 \\
\hline $46105 / 18$ & $5509(2323+3186)$ & 8,4 \\
\hline $33590 / 14$ & $5940(3220+2720)$ & 5,6 \\
\hline 30500 & $6625(2949+3676)$ & 4,6 \\
\hline $26621 / 12$ & $2208(1070+1138)$ & 12 \\
\hline 20669 / 12 & $5957(3050+2907)$ & 3,5 \\
\hline $20334 / 25$ & $3103(2115+988)$ & 6,5 \\
\hline $19378 / 12$ & $5576(2198+3378)$ & 3,5 \\
\hline 18817 & $2843(1191+1652)$ & 6,6 \\
\hline 13000 & $5803(2806+2997)$ & 2,2 \\
\hline 12516 & $1672(834+838)$ & 7,5 \\
\hline 12320 & $6000(3660+2340)$ & 2 \\
\hline 10437 & $9775(4252+5523)$ & 1 \\
\hline 9383 / 12 & $2414(1590+824)$ & 3,9 \\
\hline 8932 & $3990(2037+1953)$ & 2,2 \\
\hline 8120 & $2298(1527+771)$ & 3,5 \\
\hline 8000 & $2117(1057+1060)$ & 3,8 \\
\hline 6978 & $4463(2459+2004)$ & 1,6 \\
\hline 6701 & $2159(1356+803)$ & 3,1 \\
\hline $6011 / 12$ & $1815(666+1149)$ & 3,3 \\
\hline 3866 / 19 & $3347(2053+1294)$ & 1,1 \\
\hline 3438 & $2506(2288+218)$ & 1,4 \\
\hline 2938 / 8 & $5252(2242+3010)$ & 0,5 \\
\hline $2636 / 16$ & $3313(1303+2010)$ & 0,8 \\
\hline $2109 / 6$ & $1990(1259+731)$ & 1,06 \\
\hline 2107 & $4404(1084+3320)$ & 0,5 \\
\hline 2100 & $4417(1738+2679)$ & 0,5 \\
\hline 1720 & $878(437+441)$ & 1,9 \\
\hline 1704 & $4753(2473+2280)$ & 0,3 \\
\hline 1091 & $7850(4053+3797)$ & 0,1 \\
\hline Sin entregar & $3269(1907+1362)$ & $\mathrm{X}$ \\
\hline
\end{tabular}


por la desgracia del incendio [...] y socorro de las verdaderamente necesitadas ${ }^{21}$. Ante tamañas y tan rápidas muestras de generosidad, Campomanes propuso se fabricase un arca de tres llaves, que se depositaría en el convento de dominicos de Santo Tomás, para custodiar el legado de Garrido y cuantos donativos pudieran recibir ${ }^{22}$, propuesta que fue aprobada al día siguiente por el Consejo ${ }^{23}$. Al mismo tiempo, y confiando en la generosidad del pueblo madrileño que tan honrosos ejemplos habían de incentivar, se encargó al ministro de Hacienda, Pedro López de Lerena, la organización de una «cuestación general», dividida, para mayor eficacia, entre los diferentes cuarteles y barrios de la capital y «compuesta de Grandes Títulos y eclesiásticos condecorados» ${ }^{24}$. Lerena actuó con la mayor celeridad y a los pocos días se dio a conocer, por vía de prensa ${ }^{25}$, la lista de los sesenta caballeros nombrados para la questa pública que, según rezaba el artículo publicado en el Diario de Madrid del 24 de agosto, ya había empezado «con todo celo y actividad» ${ }^{26}$. Por lo que se refiere al propio cuartel de la plaza Mayor la colecta fue confiada al marqués de Villena y a Joaquín Díaz Bernardo (presbítero), para los barrios de las Descalzas Reales y de los Ángeles; al marqués de Montealegre y al cura párroco de San Ginés, Francisco Couque (en San Ginés y Santiago); al Marqués de Bélgica y a Gaspar de Cos, canónigo de la Real Iglesia de San Isidro (en la Panadería y Santa Cruz) y finalmente al conde de Miranda y al cura de San Justo, Gregorio de Eguileta (en los barrios de San Justo y Santo Tomás). Como evidencia este botón de muestra las autoridades acudieron efectivamente a «personas distinguidas», a las elites tradicionales, confiando la colecta en cada barrio a un binomio constituido, salvo contadas excepciones, por un representante de la alta nobleza y otro del clero ${ }^{27}$.

Como esperaban las autoridades, los madrileños, conmovidos por el terrible drama, echaron mano al bolsillo. Según el informe establecido por Joaquín

21 AHN, Consejos, leg. 3274. Nota de Campomanes a Escolano, Madrid, 17 de agosto de 1790.

$22 \quad I d$.

23 AHN, Consejos, leg. 3274. Acuerdos del Consejo, Madrid, 18 de agosto de 1790, f. 25: «Ha acordado el Consejo se diga a la Sala por medio del Sr. Gobernador de ella que para la custodia de los 30000 rs ofrecidos por D. Alfonso Garrido como de las demás cantidades que ofrezcan otras personas caritativas, y las que se colectasen de la cuestación general acordada, disponga que se forme un arca de tres llaves de las cuales tendrá una el mismo Sr. Gobernador, otra el Fiscal de la Sala y la otra el Tesorero de la misma, en cuya arca se custodien dichos caudales con la debida cuenta y razón en un libro que llevará el Escribano de Gobierno de Sala poniendo él las notas de lo que se fuese introduciendo y extrayendo».

$24 \quad$ Ibid., Acuerdos del Consejo del 17 de agosto de 1790, f. 3.

25 «Lista de los Caballeros nombrados para la questa pública», en Diario de Madrid, 24 de agosto de 1790 (núm. 236), págs. 943-947 y Memorial literario, agosto de 1790 (parte I), págs. 549-556.

26 Pág. 944.

27 Cfr. la ya citada «Lista de los Caballeros nombrados para la questa pública». 
Gómez Palacio el 30 de septiembre de $1790^{28}$ (fecha en que todavía faltaba por contabilizar el monto de colecta realizada por el duque de Alba en los barrios de Vistilla y San Andrés) la «questa general» ya había generado 478.257 reales con entregas que oscilaban, como consta en el cuadro siguiente, entre un máximo de 71.130 para los barrios de Doña María de Aragón y la Encarnación (cuartel de Palacio) y un mínimo de 1.091 para los de la Puerta de Toledo y Mira del Río (cuartel de San Francisco) mucho más populosos, pero a la par de menor monta $^{29}$.

Al producto de esta colecta general cabía agregar el de las «limosnas particulares ${ }^{30}$, que también se depositó en la famosa arca de tres llaves y representaba nada menos que 355.755 reales, así como 29.896 rs donados directamente por el duque de Medinaceli a los soldados que se emplearon en extinguir el incendio y a los conventos de la Vitoria y del Socorro para socorrer a las víctimas $^{31}$. El marqués de Villa López contribuyó el 20 de agosto con 40.000 reales, pero sólo se contabilizaron en la referida relación los 15.000 dedicados al socorro de los pobres y no los 25.000 donados para la tropa (que no se depositaron en el arca). Tampoco se valuó el donativo en especie efectuado por Juan Aguirre que contribuyó con la puesta a disposición durante ocho días de doce pares de bueyes y sus carros, más de cincuenta quesos y cinco arrobas de vino. 149.993 reales dimanaban de una subscrición lanzada por el conde de Lerena entre los empleados del Ministerio de Hacienda (según una orden comunicada por el gobernador del Consejo el 26 de septiembre) y 120.000 fueron entregados el 24 de agosto por el marqués de Astorga. Por lo que se refiere a la nobleza también contribuyeron el marqués de la Colonilla (vecino de Bilbao) con 15.000 reales (el 17 de septiembre) y mucho más modestamente el marqués de Mortara con 320 (el 11 del mismo mes). La Compañía Flamenca de Reales Guardias de Corps aportó unos 3.218 reales el 7 de septiembre. También figuraban en esta relación los 30.000 reales procedentes del ya citado Alfonso Garrido, 20.000

\footnotetext{
28 AHN, Consejos, leg. 3274: «Limosna que ha producido la Qüesta general, y existe en el Arca de tres llaves colocada en el Convento de Santo Tomás», Madrid, 30 de septiembre de 1790, 4 págs.

29 Fernando Jiménez de Gregorio, La población de la actual provincia de Madrid en el Censo de Floridablanca (1786), Madrid, Diputación Provincial de Madrid, 1984.

30 AHN, Consejos, leg. 3274: «Limosnas particulares dispensadas por los Señores que aquí se dirá, y se hallan colocadas en el Arca de tres llaves en el depósito de Santo Tomás. Para socorro de los que padecieron con motivo del Incendio ocurrido la noche 16 de Agosto de 1790», Madrid, 30 de septiembre de 1790.

$31 \quad I b i d$, pág. 2: «El Excmo. Sr. Duque de Medinaceli y Santisteban, en varios socorros hechos a los Pobres que padecieron el Incendio, y a los soldados que se emplearon en extinguirle, según la relación que acompañó 29.896 rs, los 24.000 dados a los Conventos de la Vitoria, y el Carmen Calzado 12.000 a cada uno, y los restantes, con la tropa, orden comunicada por S. E. el Señor Gobernador del Consejo en 28 de dicho agosto». La referida cantidad, que consta en el margen izquierdo de la relación, no fue tomada en cuenta en el cómputo general.
} 
reales entregados el 27 de agosto por Juan Sixto García de la Prada (del comercio de lienzos), 1.500 reales donados el 20 de agosto por Ignacio Abadía (bajo forma de veinticinco doblones, doce piezas de lienzo y doce pares de medias), los testamentarios de Francisco Vázquez ofrecieron, el 12 de septiembre, 523 reales y otros doscientos fueron entregados anónimamente el 9 de septiembre al padre prior de Santo Tomás.

\section{II.4. El celo caritativo de las comunidades religiosas}

Asimismo, nueve de las once comunidades religiosas establecidas en la cercanías de la plaza Mayor que, a petición del Consejo, dieron alimento por espacio de ocho días a las víctimas del incendio ${ }^{32}$, no solicitaron el reintegro de los gastos sufragados que, conforme a lo previsto, habían de ir a cargo del gobierno. El convento de agustinos de San Felipe el Real (calle Mayor) ni siquiera comunicó el importe originado por «el socorro de los miserables que sufrieron el desamparo, sintiendo no tener mayores facultades para manifestar su amor a la humanidad y a la patria ${ }^{33}$. El convento de dominicos de Santo Tomás (calle de Atocha), que había atendido a 240 personas, renunció a recuperar los tres mil reales gastados en agradecimiento a los «singulares favores que ha[bía] merecido al Rey, su Consejo y al público de Madrid» ${ }^{34}$. El convento de trinitarios calzados de Santo Tomás (calle de Atocha), tras afirmar cuán difícil era establecer una razón puntual de las sumas invertidas, declaró «que sería cosa ruborosa que aquella comunidad no contribuyese en algún modo al alivio y consuelo de tanto miserable ejemplo de $[\operatorname{los}]$ soberanos ${ }^{35}$. El convento de carmelitas calzados de Nuestra Señora del Carmen (calle del Carmen), que cercioraba estar en la obligación «de subvenir al Público en todas sus angustias y necesidades» y había mantenido a doscientos pobres, nada reclamó por haber gozado del apoyo económico del duque de Medinaceli ${ }^{36}$. El convento de Nuestra Señora de la Victoria de los Padres Mínimos de San Francisco de Paula (Carrera de San Jerónimo), que había suministrado comida a 148 individuos durante ocho días (también gracias a la generosidad del duque), lo hizo por espacio de otros seis días a su propio cargo, ofreciendo

\footnotetext{
32 AHN, Consejos, leg. 3274: Razón de las comunidades Religiosas y otras casas de misericordia que han dado alimento por espacio de ocho días a los necesitados con motivo del Incendio ocurrido en la plaza Mayor la noche diez y seis de Agosto de mil setecientos y noventa con expresión de las comunidades que nos solicitan reintegro, cuya razón se ha sacado del expediente en que para este fin estuvieron comisionados los Señores Alcaldes don Ignacio Luis Aguirre, y Marqués de Casa García, Madrid, 30 de septiembre de 1790, ff. 15-18 (informe establecido por Joaquín Gómez de Palacio).

33 Ibid., f. 15.

$34 \quad$ Id.

$35 \quad I d$.

$36 \quad I d$.
} 
el coste inducido como «una justa limosna debida a beneficio del Público» ${ }^{37}$. El monasterio de San Martín (de Benitos, plazuela de San Martín), que con el mismo fin había desembolsado 2.446 reales y, a la par, había mantenido a cuatro familias (en total veintidós personas) que se habían refugiado en la misma plaza, declaró cederlo todo «para socorro de los que han perdido sus efectos en el Incendio, y agradecida a las honras que les ha[bía] dispensado el Gobierno en cosas a que estaba obligada dicha comunidad por su profesión y caridad cristiana ${ }^{38}$. El capellán de las Descalzas Reales, en nombre de la Real Casa de la Misericordia (calle Capellanes), declaró que los gastos originados por la manutención de cincuenta pobres quedaba «de su cuenta privativa y personal sin grabación del Real erario ni de aquel piadoso establecimiento ${ }^{39}$. El convento de Nuestra Señora de las Mercedes (de la Merced calzada, calle de los Remedios), agradeciendo que se le hubiera solicitado para ayudar a «los pobres miserables que padecieron en el Incendio» cedió «el corte obsequio y limosnas que ha[bía] hecho por espacio de ocho días a favor de los mismos pobres, siguiendo el ejemplo de [los] Soberanos». En cuanto a la Congregación de Padres del Oratorio de San Felipe de Neri (calle Mayor), cuyos gastos ascendían a 2.356 reales, estimaba haber contribuido «por su parte a las piadosas intenciones de Rey N.S., del Consejo, y del público» y «se da[ba] por satisfecha y reintegrada de los gastos, por haberse empleado en un fin tan caritativo y propio de la consideración a los que ha[bían] padecido una desgracia tan sensible» ${ }^{40}$. Tan sólo el Oratorio de Padres del Salvador (calle Ancha de San Bernardo) y el convento de las Señoras Comendadoras de Santiago (calle de Amaniel), que invirtieron respectivamente 3.156 y 1.510 reales en la manutención de las víctimas que se les destinaron, no renunciaron al reintegro de los gastos sufragados, pero tuvieron a bien subrayar, el primero, la alegría que, a pesar de «motivos tan lastimosos» sentía por haber servido «a S. M. y al público»y, el segundo, «su pronta obediencia a las órdenes del Rey» ${ }^{41}$.

Las once comunidades aquí mentadas, no lo olvidemos, prestaron su ayuda a petición de las autoridades civiles ansiosas de aportar una solución inmediata (aunque provisional) a la extrema miseria padecida por cuantos todo lo habían perdido en la funesta noche del 16 de agosto, a una desesperanza que podía ser manantial de disturbios sociales siempre temidos. De hecho, varias fueron las comunidades que pusieron de realce el celo con que se doblegaron a la voluntad regia al mismo tiempo que rindieron homenaje al carácter bondadoso del monarca 
que fue el primero en enarbolar el glorioso estandarte de la solidaridad y de la beneficencia tan afín con sus propios valores. Deseosas de no quedar a la zaga y/o por mera caridad cristiana, no dudaron en consentir un sacrificio económico que en ciertos casos no fue nada desdeñable. A todas luces, el incendio de la plaza Mayor les brindó una magnífica oportunidad de demostrar, en una época en que abundaban las críticas en contra de un clero regular olvidadizo de sus deberes más elementales, que tamañas acusaciones carecían de fundamento y que las ordenes religiosas estaban, como Dios manda, al servicio de los necesitados.

\section{II.5. La contribución de la Real Sociedad Económica de Amigos del País de Madrid}

La Real Sociedad Económica Matritense, dirigida a la sazón por el conde de Floridablanca, tampoco permaneció inactiva ante el drama. En la junta del 21 de agosto, el marqués de Castrillo (que presidió la sesión en su calidad de subdirector) evocó la triste situación de cuantos por motivo del incendio habían quedado «en indigencia, y sin poder ejercer sus artes, y oficios» y afirmó que esta «era una ocasión muy oportuna para que el Rl Cuerpo concurriese con cuanto le permit[iesen] sus facultades al alivio de una necesidad tan recomendable». Pero, «atendida la generosidad de S. M., y la caridad de tantos como se han propuesto socorrerlos», los socios decidieron participar al esfuerzo colectivo proporcionando instrumentos a los artesanos que los hubieran perdido durante el incendio y se hallaban por lo tanto en la imposibilidad de ganarse el jornal ${ }^{42}$, lo que dieron a conocer por vía de prensa, como consta en el Diario de Madrid del 26 de agosto de 1790:

La Real Sociedad Económica, particularmente excitada al bien público por su instituto en la presente calamidad, ofrece a los Artesanos que por el incendio hayan perdido los instrumentos de su ejercicio, habilitarlos para el trabajo hasta donde alcancen sus fondos, dándoles los expresados instrumentos. A este fin se tomarán los Informes convenientes, advirtiendo que no se deben ser partícipes los socorridos competentemente por las cuantiosas limosnas de SS. MM., Personas Reales, y particulares ${ }^{43}$.

La propuesta no cayó en saco roto. Al día siguiente de publicarse el anuncio, el 27 de agosto, llegó la primera solicitud. Blas Antonio Alejandro, zapatero, que vivía con su madre en la escalera de San Francisco, Portal de Paños, n. ${ }^{\circ} 38$ (sexto

\footnotetext{
42 Archivo de la Real Sociedad Económica Matritense de Amigos del País (ARSEMAP), Libro de Acuerdos núm. 8 (A/110/15), junta del 21 de agosto.

43 Diario de Madrid, 26 de agosto de 1790 (núm. 238), pág. 956.
} 
piso) y declaraba haber perdido «todos sus efectos, y ropas» así como «todas las herramientas, con que trabajaba en su cuarto» y estar en la imposibilidad de reponerlas, solicitaba de la noble institución le socorriese «con lo que fuere de su agrado, para el fin de habilitarse, y poder trabajar a su oficio» ${ }^{44}$. Y fue entendido sin mayor demora ya que, a principios de septiembre, recibió herramientas por un monto de $98 \mathrm{rs} \mathrm{y} 22 \mathrm{mrs}^{45}$. Sin embargo, pese a sus buenas intenciones y a la urgencia de la situación, la Matritense, no destacó inicialmente por su celeridad. Con el fin de evitar eventuales abusos (y por lo tanto de limitar los gastos), actuó con la mayor cautela.

En junta del 2 de octubre, el secretario, Tejada Hermoso, hizo saber a los nueve socios presentes ${ }^{46}$ que ya había recibido ocho memoriales de artesanos y que estos «instaban frecuentemente haciendo presente su estado de miseria a que les había reducido el incendio de la plaza Mayor». Pero la «Junta enternecida» tan sólo acordó entonces se creara posteriormente una comisión encargada de informar sobre los socorros que hubieran recibido del Gobierno, antes de tomar cualquier medida, y decidió se contestara a los pretendientes que se les atendería «a su tiempo» ${ }^{47}$. Finalmente, el 23 de octubre entregaron el expediente de los artesanos a Josef Arias de Villafañe para que investigara sobre su situación ${ }^{48}$. Como expresó en el informe que remitió a la Sociedad el 5 de noviembre, el conde cumplió a rajatabla y sin demorarse con su cometido. Comprobó personalmente que los datos proporcionados por los solicitantes (identidad, domicilio, situación económica) eran exactos, acudió a especialistas de cada oficio para determinar si los instrumentos pedidos eran los apropiados, visitó a los mercaderes para hacerse una idea cabal de los precios de dichas herramientas y tuvo el placer de comprobar que varios comerciantes aceptaron rebajarlos para cooperar con los «piadosos fines de la Real Sociedad». Finalmente, estimando que «con dar dinero se frustra el fin» propuso efectuar él mismo las compras, aunque fuera acompañado por los artesanos a las tiendas y solicitó para ello un presupuesto de dos mil reales que le fue librado el 17 de noviembre ${ }^{49}$.

\footnotetext{
44 ARSEMAP, leg. 115, doc. 3: Expediente de los concurrentes a las ofertas de la Real Sociedad en el Diario de 26 de Agosto de 1790 y han perdido sus bienes en el Incendio de la plaza / año de 1790. Solicitud de don Blas Antonio Alejandro, Madrid, 27 de agosto de 1790.

45 Id. Una primera factura que arroja un monto de 59 rs y $22 \mathrm{mrs}$ (por 3 cuchillas, 2 martillos, una costa, una chaira, 3 bisagras, 5 alesnas y 2 tenazas) firmada por Josef Arias de Villafañe fue establecida el 8 de septiembre. Sin embargo el acuse de recibo firmado por el solicitante (que incluye a la par 1 mesa, 1 huevo y 3 pares de hormas) y arroja un monto total de $98 \mathrm{rs} \mathrm{y} 22 \mathrm{mrs}$ no lleva fecha.

46 Almarza, Irisarri, Villafañe, Ambrona, Alvarellos, Riquelme, Barba, Vargas y Romaña.

47 ARSEMAP, Libro de Acuerdos núm. 8 (A/110/15), junta del 2 de octubre.

48 Id., junta del 23 de octubre.

49 ARSEMAP, leg. 115, doc. 3: Josef Arias de Villafañe y Miranda informa a la sociedad de la certeza, identidad y necesidad de todos los concurrentes a los socorros de dicho Rl Cuerpo, con motivo del Incendio de
} 
Finalmente, de las veintidós solicitudes que recibieron entre el 27 de agosto de 1790 y el 21 de enero de 1791, sólo la presentada por Felipe Arnao (oficial de monterero) fue denegada, por haber perdido en el incendio bienes muebles, pero no profesionales. El conde de Villafañe, que no le había comprado herramientas por no tener aquel tienda, estaba sin embargo dispuesto a donarle sesenta reales para que pudiera «trabajar por sí» ${ }^{50}$. Pero la junta general del 5 de marzo,

[...] enterada, como igualmente de que la suplica del interesado se reduce a pedir una limosna para el restablecimiento de su mujer, y desempeñarse de sus deudas, y también que no habiendo perdido herramientas no era comprendido en las ofertas de este Real cuerpo con motivo del incendio, acordó no haber lugar a la solicitud de este artesano ${ }^{51}$.

Finalmente, el 30 de abril de 1791, Villafañe dio su comisión por concluida tras haber proporcionado a veintiún artesanos diversas herramientas por un importe total de 3.521 reales y 22 maravedís. Sensible a la penosa situación en que se hallaban los solicitantes y con el fin de reducir los plazos de entrega de los utensilios, el celoso conde no dudó en desembolsar los 1521 reales que faltaban para satisfacer las demandas ${ }^{52}$. Ese gesto, así como la eficacia con que había cumplido su cometido, le valieron el agradecimiento de la junta que se reunió ese mismo día y pidió al tesorero le librara "sin dilación» la suma que había anticipado, al mismo tiempo que se encargaba a la Secretaría establecer «una relación circunstanciada de este expediente para hacerla presente en la primera Junta pública de distribución de premios ${ }^{53}$.

Conforme a lo previsto, no se omitió durante la Junta general de distribución de premios celebrada el 29 de diciembre de 1791 (acto solemne y público que permitía lucir la obra realizada por la Sociedad a lo largo del año) recordar ante la dilatada asistencia «los generosos y caritativos oficios [del] Cuerpo Patriótico en una de las mayores calamidades públicas que han acaecido en este tiempo ${ }^{54}$. Con harta emoción se evocó

la plaza Mayor, que socorre a los que, en necesidad extrema, ofrece presenciar la compra de herramientas y dice serán necesarios como 2 mil rs de vn, Madrid, 5 de noviembre, 3 págs.

50 ARSEMAP, leg. 115, doc. 3: Expediente referente a Felipe Arnao (Carta de solicitud, Madrid, 21 de enero de 1791, 3 págs. e informe al respecto de Villafañe, 2 págs.)

51 ARSEMAP, Libro de Acuerdos núm. 9 (A/110/17). Junta general del 5 de marzo de 1791.

52 ARSEMAP, leg. 115, doc. 3. Informe del conde Villafañe, 30 de abril de 1791.

53 ARSEMAP, Libro de Acuerdos núm. 9 (A/110/17). Junta del 30 de abril de 1791.

54 ARSEMAP, Libro de Acuerdos núm. 9 (A/110/17). Junta general de distribución de premios del 29 de diciembre de 1791. 
[...] aquel día terrible, aquel día de confusión, y de horror en que apoderado el más voraz elemento de una cuarta parte de la plaza pública, no parecía sino querer envolverlo todo en llamas, y reducir aun a los míseros mortales a paveras y cenizas. Ni consejos acertados, ni la pronta ejecución, ni la animosidad de la tropa, ni el arte de la experiencia, pudieron impedir que fuese un verdadero desastre. Las calles y la plazas resonaban a un tiempo con las devotas súplicas, y plegarias del enternecido vecindario, y con las lágrimas, y querellas de los miserables a quienes privaba de su comodidad, de sus pobres ajuares, y aun de las herramientas precisas de su oficio el inexorable incendio que todo lo devoraba ${ }^{55}$.

Se subrayó cómo, en medio de tamaña confusión, la Matritense, sin prescindir de «aquellos oficios de piedad y conmiseración que dicta a todos la naturaleza», combinó «la caridad y la sabiduría» para prestar su ayuda a los menesterosos y permitió a varias familias de «artesanos honrados» recobrar la esperanza ${ }^{56}$. Tampoco faltó la conmovedora referencia a la reacción de los artistas socorridos, como consta en el libro de acuerdos de la Matritense:

¡Con cuántas bendiciones acompañaron aquellos pobres artesanos la recepción de los instrumentos de su oficio! Con qué ojos tan placenteros miraban aquellas herramientas que si habían de fatigar sus miembros, y sacar el sudor a su rostro, habían de ser también un capital de cuyo producto se sustentasen muchas familias para lustre de la Religión y aumento del Estado ${ }^{57}$.

Lejos de proporcionar una cuenta y razón de las sumas invertidas en alivio de esas víctimas del incendio, la sociedad, poniendo de realce los benéficos frutos de una beneficencia sabia y racionalmente distribuida, privilegió, para mayor gloria de la institución, el campo de la emoción. Huelga decir que, al fin y al cabo, los 3.521 rs y $22 \mathrm{mrs}$. desembolsados por la Matritense poco representaban en comparación con la generosidad de algunos meros particulares. Aunque harto simbólicos, constituían una humilde gota entre el mar de donativos generado por la tragedia. Cuanto más que el cuerpo patriótico, integrado por lo más granado de la sociedad, disponía en noviembre de 1790 de una tesorería de más de 100.000 reales $^{58}$. A poca costa la Matritense había aportado su piedra al edificio de la

$\begin{array}{ll}55 & \text { Id. } \\ 56 & I d . \\ 57 & I d .\end{array}$

58 ARSEMAP, Libro de Acuerdos núm. 9 (A/110/17). Junta de 8 de enero de 1791: «Estado de los caudales de la Tesorería del mes de Noviembre de 1790 / Hice presente el estado de los caudales de la tesorería, que remitió nuestro tesorero el Sr. don Joseph Almarza, por el cual consta, que en fin de noviembre del año anterior 
Lista de los veintiún artesanos socorridos por la Matritense

\begin{tabular}{lll} 
Nombre y apellidos & Profesión & Domicilio o lugar de hospedaje \\
\hline Blas Antonio Alejandro & zapatero (oficial) & Esquina de la calle de San Pedro \\
Juan de Dios Bris Baldeón & platero (oficial) & $\begin{array}{l}\text { Plazuela de S. Francisco } \\
\text { (en la fábrica de tiradores de oro) }\end{array}$ \\
Francisco Fábrica & zapatero (oficial) & $\begin{array}{l}\text { Plazuela del Cordón } \\
\text { (en casa de Mariano Colón) }\end{array}$ \\
Manuel González & carpintero (oficial) & Portal de Mauleros, rincón de la Cruz \\
Andrés del Cerro & carpintero (ayudante) & Calle de la Sal Taberna \\
\hline Manuel Valera & zapatero & Pasadizo del Conde de Oñate \\
Bernardo Palencia & zapatero (maestro) & Calle de la Amargura \\
Juan Joseph Rodrigo & zapatero & Pasadizo del Conde de Barajas \\
Juan Artal & sastre (maestro) & Calle Jacometrezo \\
Julián Cuevas & monterero (maestro) & Calle de la Amargura \\
\hline Vicente Antuñano & platero de oro (oficial) & En la plaza \\
Ramón de Peña & monterero (maestro) & Calle de Toledo \\
Antonio María & sastre (oficial) & Puerta de Guadalajara, n. ${ }^{\circ} 5$ \\
Pedro López & peluquero (oficial) & Puerta de Guadalajara \\
Manuel Sevillano & cofrero & Portal de Cabestrazos, n. ${ }^{\circ} 12$ \\
\hline Josef Frigola & carpintero & Calle del Barquillo, n. 5 \\
Francisco Sarda & sastre (oficial) & Guardilla del Conde del Carpio \\
Gregorio Cantero & sastre (oficial) & Guardilla del Conde del Carpio \\
Juan Estepa & zapatero (oficial) & Guardilla del Conde del Carpio \\
Tomás Oliva & zapatero & Guardilla del Conde del Carpio \\
Isidro Elías & Guardilla del Conde del Carpio \\
\hline Total & & \\
\hline & & \\
\hline
\end{tabular}

Fuente: ARSEMAP, leg. 115 , doc. $3 .^{59}$

existían en las arcas 103170 rs y 15 mrs de v. ón , de que quedó enterada la Junta, acordando que se guarde en secretaría con los anteriores».

59 El referido expediente incluye para cada artesano la carta de solicitud que remitió, la lista de herramientas que se le donaron (con indicación del precio de cada una), así como el acuse de recibo por las mismas. 


\begin{tabular}{|c|c|c|}
\hline Fecha solicitud & $\begin{array}{l}\text { Fecha de entrega } \\
\text { de las herramientas }\end{array}$ & Importe rs/mrs \\
\hline 27-08-1790 & 8-09-1790 & 98 rs 22 \\
\hline $31-08-1790$ & $\mathrm{x}$ & 362 \\
\hline $1-09-1790$ & $\mathrm{x}$ & 154 \\
\hline $2-09-1790$ & $\mathrm{x}$ & 208 \\
\hline $3-09-1790$ & $9-11-1790$ & 197 \\
\hline $6-09-1790$ & $\mathrm{x}$ & 132 \\
\hline 10-09-1790 & $15-11-1790$ & 100 \\
\hline 20-09-1790 & 8 у 16-11-1790 & 177 rs 17 \\
\hline $26-11-1790$ & $\mathrm{x}$ & 278 \\
\hline $12-11-1790$ & 6-01-1791 & 113 \\
\hline $15-11-1790$ & $10-01-1791$ & 337 \\
\hline $17-11-1790$ & 6-01-1791 & 113 \\
\hline $\mathrm{x}$ & $20-12-1790$ & 60 \\
\hline $\mathrm{x}$ & $20-12-1790$ & 100 \\
\hline $3-12-1790$ & $22-01-1791$ & 178 \\
\hline $29-12-1790$ & $\mathrm{x}$ & 70 \\
\hline 11-01-1791 & $14-02-1791$ & 199 \\
\hline 11-01-1791 & $14-02-1791$ & 199 \\
\hline 11-01-1791 & 21-01-1791 & 160 rs 17 \\
\hline 11-01-1791 & 21-01-1791 & 136 \\
\hline \multirow[t]{2}{*}{ 11-01-1791 } & 20-01-1791 & 149 \\
\hline & & $3521 \mathrm{rs} 22 \mathrm{mrs}$ \\
\hline
\end{tabular}


solidaridad y reforzado su imagen de piadosa institución al servicio del bien público. Lo demás era lo de menos.

\section{Gastos a la altura del desastre}

No faltaron pues los actos caritativos (espontáneos o inducidos, espectaculares o humildes) y los fondos recaudados fueron importantes, quizás más de lo que se hubiera podido esperar. Pero también lo fueron los gastos ocasionados por el incendio. Basta para convencerse de ello recorrer las cuentas establecidas por Juan Antonio Cancio, cajero principal de la Tesorería General de la Villa. Entre el 19 de agosto y el 25 de septiembre (periodo cubierto por el primer estado que transmitió a la Contaduría de Cuentas ${ }^{60}$ ) abonó facturas por un monto de 280.998 reales, todas relativas a la mera extinción del incendio: 181.889 reales se destinaron al pago de albañiles, carpinteros y peones $^{61}, 25.515$ al de los trabajadores que transportaron el agua de las fuentes de Madrid a las bombas de la plaza Mayor ${ }^{62}, 8.076$ a quienes las repararon y manejaron $^{63}$, 311 al pago de varios jornales sin mayores precisiones ${ }^{64}$. Se gastaron 1.518 reales para el alquiler de los «baños» que se dispusieron en distintos lugares para constituir reservas de aguas con que surtir las bombas ${ }^{65}, 2.324$ para la compra de $\operatorname{cubos}^{66}, 2.258$ para la del yeso destinado a la construcción de atajadizos ${ }^{67}, 10.309$ para la extracción de escombros ${ }^{68}$ y 398 para el alquiler de mulas y $\operatorname{carros}^{69}$. 1.337 se destinaron al pago de varios maestros de oficios, de los gastos de tablado y gradería generados por la construcción del altar que se dispuso en la misma plaza, así como de varios géneros entre los cuales dos fundas y cuatro colchones de terliz destinados a los cuatro regidores que se

\footnotetext{
60 Ahn, Consejos, leg. 3274: Cuenta que don Juan Antonio Cancio, Cajero principal de la Tesorería general de esta Villa, doy en virtud de orden del $S^{o r}$ Corregidor de Madrid de 26 del presente mes consecuente a otra del Excmo. Sr. Gobernador del consejo de los Caudales que han entrado en mi poder, e invertídose por mi mano en los gastos causados en auxiliar, y atender la extinción del fuego de la plaza Mayor en virtud de nombramiento que para evacuar esta comisión hizo Madrid, en mi, por su Acuerdo de 19 de Agosto próximo pasado, desde cuyo día comprende esta cuenta hasta 25 de septiembre del presente año, Madrid, 2 de octubre de 1790, $18 \mathrm{ff}$.

$61 \quad$ Ibid., ff. 2-5.

$62 \quad$ Ibid., ff. 5-6.

63 Ibid., ff. 6-7.

$64 \quad$ Ibid., f. 12.

65 Ibid., ff. 12-13.

66 Ibid., ff. 14-15.

67 Ibid., f. 15.

$68 \quad$ Ibid., f. 6.

69 $\quad$ Ibid., f. 14.
} 
alternaron en las guardias ${ }^{70} .993$ reales se utilizaron para adquirir varios efectos destinados a facilitar la labor de cuantos sin cesar actuaban en la plaza: faroles, velas de sebo, candeleros, aceite, garruchas... ${ }^{71}$ Para mantener a los numerosos operarios contratados, se gastaron 21.537 reales en queso $^{72}, 10.210$ en raciones de pan $^{73}, 1.435$ en vino ${ }^{74}$ así como 12.392 para las comidas, cenas y refrescos de los ministros y justicia ${ }^{75}$. Y finalmente 240 reales se emplearon en el traspaso de los documentos del archivo del repeso mayor a la Cárcel de Corte $^{76}$.

El 7 de diciembre de 1790 Juan Antonio Cancio produjo un nuevo estado relativo esta vez a los gastos realizados desde el 26 de septiembre, también referentes a las operaciones de extinción y desbroce, los cuales supusieron el desembolso de otros 68.181 reales $^{77}$. O sea que fueron necesarios casi 350 mil reales para hacer frente tan sólo a las intervenciones de primera urgencia.

\section{IV. «Los buitres carnívoros»}

La catástrofe generada por el incendio dio lugar a una gran ola de solidaridad y de generosidad. Los donativos privados o institucionales abundaron. Varios miembros de comunidades religiosas acudieron inmediatamente a la plaza Mayor. Algunos ayudaron a sacar de las casas a las personas y parte de sus bienes. Otros prefirieron el rezo a la acción y se apresuraron en organizar procesiones y en traer imágenes. Particulares se propusieron para alojar a amigos, conocidos o incluso extraños que habían visto sus casas desaparecer entre las llamas. «[Ante] la consternación general en que se hallaban todas las gentes por

$70 \quad$ Ibid., ff. 13-14.

${ }^{71} \quad$ Ibid., ff. 15-16.

72 Ibid., ff. 7-8.

73 Ibid., ff. 8-10.

74 Ibid., ff. 10-11.

75 Ibid., f. 11.

76 Ibid., f. 16.

77 AHN, Consejos 3274: Cuenta que don Juan Antonio Cancio Cajero General de la Tesorería general de Madrid, doy en virtud de Orden del Consejo de veinte y cuatro de Noviembre de este año, cumplimentando por el Ilmo. Ayuntamiento de esta Villa de veinte y cinco del mismo mes, de los caudales que entraron en mi poder, e invirtieron por mi Mano en los gastos causados en la continuación de auxiliar, y atender a la extinción del fuego de la plaza Mayor, consecuente al nombramiento que para evacuar esta comisión hizo en mi Madrid por su acuerdo de diez y nuevo de Agosto del presente año, y comprende desde veinte y seis de septiembre del corriente (siguiente al ultimo que incluía la cuenta primera que presenté con sus respectivos recados de justificación) hasta el día de la fecha; y con cargo y Data, Madrid, 7 de diciembre de 1790, $7 \mathrm{ff}$. 
el presente formidable incendio» se cerraron, a petición de la Villa, los teatros públicos y se postergó la fiesta de toros prevista para el día $19^{78}$.

Pero tampoco faltaron quienes, insensibles al dolor y a la desesperanza de las víctimas, intentaron sacar fruto de la situación como lo induce, por ejemplo, un edicto firmado el 18 de agosto (a los dos días de declararse el incendio) que se dio a conocer por vía de prensa y mediante carteles fijados en los lugares acostumbrados de la Corte. En él se podía leer lo siguiente:

\begin{abstract}
Habiéndose notado que los Carruajeros y Trajineros, Mozos de cordel y Conductores, aprovechándose de la presente calamidad, han alterado considerablemente los precios de la conducción de muebles y efectos con el perjuicio que se puede considerar a los miserables dueños que han sentido los efectos de este incendio, se manda que ninguno se atreva a alterar dichos precios, ni se oculten ni puedan excusarse con pretextos afectados o frívolos a concurrir con sus carros, caballerías y personas, cuando sean buscados so pena de cien ducados y dos meses de cárcel; y no teniendo bienes serán destinados por seis meses al camino Imperial... ${ }^{79}$.
\end{abstract}

A la par, como no suele haber mayor aliciente que el dinero, se estipuló que el importe de dichas multas se repartiría, a razón de un tercio cada uno, entre el delator, los ministros de justicia y las víctimas.

Ante el desorden y el caos generado por el siniestro, y «siendo muy regular que entre las ruinas del incendio ocurrido en la plaza Mayor se hall[as]en muchas alhajas, moneda y pasta pertenecientes a los vecinos que habitaban aquellas casas», el Consejo mandó publicar el 21 de agosto un bando relativo a la «seguridad pública y de los vecinos» ${ }^{80}$ en el cual se indicaban con suma precisión las providencias tomadas por las autoridades con el fin de evitar, en lo posible, ocultaciones y robos, así como para averiguar quienes eran los verdaderos dueños de los bienes y efectos extraídos de las casas incendiadas. El referido bando constaba de diez capítulos que, se subrayaba, habían de ser respetados «por todos, sin excepción de personas, de cualquier calidad o fuero que sean» ${ }^{81}$. Se pedía a cuantos hubieran aceptado por caridad la custodia de bienes procedentes de la plaza («fueran seglares, eclesiásticos o religiosos») actuaran con la mayor cautela a la hora de restituirlos, cerciorándose previamente de la identidad de los propietarios y exigiendo de ellos un recibo. Para evitar fraudes y pleitos, se pidió a dichos depositarios entregaran en un plazo de quince días en la Escriba-

\footnotetext{
78 AVm, Libro de Acuerdos núm. 220, Junta de Ayuntamiento del 17 de agosto de 1790, f. 162.

79 Cartel reproducido en el Diario de Madrid, 19 de agosto de 1790 (núm. 231), pág. 926.

80 AHn, Consejos, leg. 3274. Cfr. Acuerdos del la Junta del Consejo Pleno del 20 de agosto de 1790.

81 Bando reproducido en el Diario de Madrid, 22 de agosto de 1790 (núm. 234), págs. 935-937.
} 
nía de Gobierno la lista de los bienes en su poder, so pena de ser considerados como auténticos ladrones. Se invitaba al mismo tiempo a los moradores de las casas incendiadas a que se dieran a conocer cuanto antes y comunicaran a las autoridades la lista jurada de los efectos que consiguieron salvar (indicando, cuando fuese dable, donde habían sido depositados) y de los que podrían hallarse entre las ruinas. Se prohibió a los artesanos (plateros, sastres, prenderos...) y a todo el vecindario comprasen cualquier tipo de mercancía fuera de las tiendas, invitándoles a denunciar a los vendedores que juzgaran sospechosos. Se estipuló a la par que ningún efecto procedente de la plaza podría ser extraído fuera de Madrid sin previa autorización de un juez, exponiéndose los conductores a perder, en caso de infracción, sus carruajes y caballerías «sin que les valga el pretexto de la ignorancia». Se hizo saber a los mozos de cordel que no podrían transportar efectos de una casa a otra tras el toque de las Oraciones so pena de ser destinados por un año al Canal Imperial. Se vedó a los propietarios o inquilinos de las casas incendiadas la posibilidad de reconocer las ruinas, tanto de noche como día, autorizándoles sin embargo, tras aviso judicial, a disponer guardias en los lugares donde vivían.

Asimismo como consta en el Diario de Madrid del 25 de agosto, fecha en que se iniciaron las obras de desbroce, se procedió a la construcción de una cerca «de conveniente altura» y con varias puertas para aislar la totalidad de la zona afectada por el incendio, con el objeto no sólo de acrecentar la seguridad de las personas sino también de luchar con mayor eficacia contra los robos y de disminuir la fatiga de la tropa, siendo necesarias menos centinelas para vigilar el recinto ${ }^{82}$. A la par se mandó construir un cuartel provisional para acoger a los cuarenta hombres que habían de resguardar los efectos y despojos del incendio ${ }^{83}$. Ante tamaño despliegue de medidas destinadas a garantizar la seguridad de las personas y de los bienes, huelga decir que el incendio no generó exclusivamente una gran ola de solidaridad, como recalcó el autor de un artículo satírico, que con fecha del 30 de septiembre de 1790, salió a la luz en La Espigadera ${ }^{84}$. Presentándose como testigo ocular del drama, el impertinente corresponsal del periódico

82 Diario de Madrid, 26 de agosto de 1790 (núm. 238), págs. 957-958: «Se está practicando en la plaza una cerca de conveniente altura con sus puertas correspondientes, y continuará por todo el recinto que ha comprendido el fuego, a fin de que quedando encerradas las ruinas de los Edificios incendiados, hasta que se hallen en estado de ser transportadas a otros parajes, se eviten las desgracias, y aun los robos que pueden acontecer con la proximidad de las gentes, logrando al mismo tiempo disminuir la fatiga a la Tropa, pues con menos centinelas quedará custodiado el todo».

83 Avм, Libro de Acuerdos núm. 220. Cfr. juntas del 2 de septiembre (f. 173), 4 de septiembre (f. 174) y 7 de septiembre (ff. 176-177).

84 «Carta irónica de un Extranjero a un Paisano, en que le participa algunas observaciones hechas por sí mismo, durante el fuego acaecido en la plaza Mayor de esta Corte el 16 de Agosto de este año de 1790», en La Espigadera, tomo I, núm. 1, págs. 27-37. 
describió con no poca sorna «el tropel de mirones» que al no tener «instrumentos para apagar el fuego, buscaron con exquisita diligencia los que pudieron para apagar su codicia» y se emplearon con fogosidad en «socorrer los metales, que sin el auxilio de estas piadosas almas hubieran perecido irremediablemente» ${ }^{85}$. Y cuál no fue su admiración al ver un extranjero (español no podía ser) que

[...] a imitación de la gallina de Esopo, un bolsillito de escudos, que su caridad había podido haber a las manos, y no tenía faltriquera donde depositarlos, se los iba engullendo con mucho modo, para después en sus áureas deposiciones hallar un verdadero tesoro escondido entre el mismo estiércol ${ }^{86}$,

tal como hicieron en su tiempo algunos judíos que no se resignaron a abandonar la Península, dejando tras ello todo su oro. ¿Existió verdaderamente el rapaz extranjero, o nació de la jocosa y mordaz imaginación del literato? Al fin y al cabo, poco importa. Aunque fuese ficticio, algo tendría de real y de ejemplar. A todas luces, los buitres no faltaron como tampoco se echaron de menos los curiosos. El devastador fuego de la plaza Mayor, «la mayor calamidad» que se había podido presenciar en aquel tiempo (en palabras de los socios de la Matritense) se había convertido en todo un acontecimiento que rayaba en lo espectacular.

\section{De la información al sensacionalismo}

\section{V.1. La prensa cuenta el drama}

Con lo cual no es de extrañar que la prensa madrileña se hiciera eco de lo acontecido. El Memorial literario, instructivo y curioso de la Corte de Madrid (por entonces bimensual), que gozaba de un éxito nada desdeñable como demuestra su tremenda longevidad (1784-1808) y contaba con numerosos suscriptores en provincias $^{87}$, dedicó al asunto cuatro artículos, publicados en agosto, septiembre y diciembre de $1790^{88}$. Actuando como auténticos reporteros, los memorialistas

85 Ibid., pág. 33.

86 Ibid., pág. 34.

87 Elisabel Larriba, Le Public de la presse en Espagne à la fin du XVIII siècle (1781-1808), París, Honoré Champion, 1998, págs. 80-84.

88 «Noticias del incendio de la plaza Mayor de Madrid, que empezó en la noche del 16 de agosto», en Memorial literario, agosto de 1790 (parte I), págs. 532-528; «Noticias ulteriores de resultas del incendio de la plaza Mayor», en id., septiembre de 1790 (parte I), págs. 68-78 + 1 lámina acompañada de «Explicación del plano» (1 pág.); «Muestra de la beneficencia del señor duque de Medinaceli y Santistebán, en el socorro del incendio de la plaza Mayor de Madrid la noche del 16 de agosto», en id., septiembre de 1790 (parte II), págs. 149-152 y «Bando y avisos posteriores al incendio de la plaza Mayor», en id., diciembre de 1790 (parte I), págs. 481-492. 
informaron a sus lectores con suma precisión (el primer artículo constaba de veintisiete páginas) sobre las circunstancias en que estalló el incendio, la celeridad con que se extendió, los estragos que causó y cómo, gracias a la inmediata movilización de las autoridades, se organizaron los socorros. Rindieron homenaje a la labor de cuantos, nada más dada la alerta lucharon contra el fuego, esforzándose en salvar «la vida a tanto número de personas que habitaban en la plaza en cuartos muy altos, escaleras estrechas, mucha gente acostada, desprevenida, turbada y no acertando casi con sus propios bultos y los de su familia» ${ }^{89}$. Llamaron la atención del público sobre «el esmero de la tropa y paisanaje» ${ }^{90}$. Para ello se valieron a menudo de casos concretos destacando por ejemplo el «valor e intrepidez» de D. Juan de Armada (teniente del regimiento de Reales Guardias españolas) y D. Francisco Solano (Segundo ayudante), quienes, con los gastadores del Regimiento de Infantería de la Corona, consiguieron, arriesgando su vida, extraer en unas pocas horas setecientos cincuenta maderos de los edificios incendiados ${ }^{91}$.

Evocaron con no poca emoción la tragedia vivida por «las más de las familias cercanas al principio del fuego [que] no pudieron salvar sino sus personas, y aun no sus ropas para poder salir vestidos, y sin tener adónde ir a parar la noche ni el resto de los días» ${ }^{92}$. Tampoco faltaron las referencias al amplio movimiento de solidaridad que, cobrando varias modalidades, se propagó con una honrosa celeridad. Como subrayaron con cierto orgullo «se vio mucha compasión y generosidad en los vecinos, que con la mayor ternura recibían en sus casas a sus amigos y conocidos, y aun extraños, o bien sus ropas o alhajas, o cosas de cuidado, depositándolo fielmente ${ }^{93}$. Pusieron de realce la pronta reactividad de las comunidades religiosas que «desde el punto del incendio acudieron a las casas para ayudar a sacar las personas y muebles que pudiesen y tenerlos en guardia, y consolar en semejantes aflicciones a los atribulados». Otras, subrayaron, «se emplearon en rogativas y súplicas al Señor Sacramentado implorando su misericordia», como fue el caso de los trinitarios descalzos, que

[...] trajeron aquella noche en procesión la Imagen de Jesús de Nazareno a la vista del incendio, y le colocaron hasta el día 18 por la mañana en la Parroquial de Santa

89 «Noticias del incendio de la plaza Mayor de Madrid, que empezó en la noche del 16 de agosto», op. cit., pág. 535 .

90 «Noticias ulteriores de resultas del incendio de la plaza Mayor», op. cit., pág. 71.

$91 \quad$ Ibid., págs. 71-72.

92 «Noticias del incendio de la plaza Mayor de Madrid, que empezó en la noche del 16 de agosto», op. cit., pág. 536 .

$93 \quad$ Ibid., pág. 539. 
Cruz, a donde también el Cabildo había traído la imagen de San Roque, que en la tarde del mismo día habían sacado en procesión general ${ }^{94}$.

Tampoco omitieron precisar que, a petición del Consejo, varios conventos ofrecieron «abundancia de raciones para que fuesen a comer los que no tuvieran disposición para ello, y para los pobres trabajadores» ${ }^{95}$ y que

[...] para mayor comodidad de los trabajadores en apagar el incendio, con permiso de los Prelados Eclesiásticos, se dispuso un Altar bajo del Arco de la Real Casa de la Panadería, en donde se celebró suficiente número de Misas, habiéndose comenzado el día $22^{96}$.

Con la esperanza de favorecer un clima de emulación, destacaron el celo caritativo de ciertos particulares. De ahí la publicación, como vimos, de un artículo dedicado exclusivamente a la «Muestra de beneficencia del Excelentísimo Señor Duque de Medinaceli» ${ }^{97}$. Y como era de esperar también pusieron de realce la implicación y la generosidad de la familia real antes de hacer referencia a la famosa colecta general organizada a propuesta del Consejo ${ }^{98}$. A la par, convirtiéndose en portavoz del poder, insertaron en sus páginas los numerosos bandos, edictos o avisos motivados por el incendio ${ }^{99}$. Pero tampoco se olvidaron de las preocupaciones del vecindario. Así, reprodujeron en el número de septiembre el informe elaborado ese mismo mes a petición del marqués de Santa Cruz por don Pedro Gutiérrez Bueno, «Sobre la salubridad del aire de la plaza Mayor» ${ }^{100}$. En dicho artículo el catedrático de química exponía los experimentos que había practicado para evaluar la calidad del aire en varios lugares del perímetro afectado por la catástrofe y los recursos que convenía adoptar para propiciar su saneamiento. Concretamente proponía

[...] se colocasen varios hornillos en las inmediaciones del incendio, y en cada uno un puchero sin vidriar con la Manganesa, haciendo ascua esta substancia, se

\footnotetext{
$94 \quad$ Ibid., pág. 538.

95 Ibid., págs. 537-538.

«Noticias ulteriores de resultas del incendio de la plaza Mayor», op. cit., pág. 68.

En núm. de septiembre de 1790 (parte II), págs. 149-152.

«Noticias ulteriores de resultas del incendio de la plaza Mayor», op. cit., págs. 536-537.

«Noticias del incendio de la plaza Mayor de Madrid, que empezó en la noche del 16 de agosto», op. cit., págs. 539-558 y «Bando y avisos posteriores al incendio de la plaza Mayor», op. cit., págs. 481-492.

100 «Informe de D. Pedro Gutiérrez Bueno, Catedrático de Química, al Excmo. Señor Marqués de Santa Cruz, sobre la salubridad del aire de la plaza Mayor», en Memorial literario, septiembre de 1790 (parte I), págs. 73-78.
} 
desprendería el oxígeno que contiene, y reemplazaría al aire la cantidad que le falta para ser bueno para la respiración.

Asimismo invitaba «a todos los vecinos de aquellas inmediaciones, hiciesen hervir en sus hogares un poco de vinagre, para que este descompuesto por el calor diese oxígeno, y contribuyese con más prontitud a lograr el fin que se debe desear» ${ }^{101}$. Y para mayor esclarecimiento y satisfacción del público, los memorialistas completaron este artículo científico utilitario, con un plano de la plaza y sus inmediaciones que permitía apreciar con toda precisión el terreno recorrido por el fuego en esta ocasión así como durante los incendios de 1631 y 1672. El carácter excepcional del acontecimiento bien se merecía ese lujo iconográfico que pocos periódicos podían permitirse y que los memorialistas solían reservar a temas de la mayor trascendencia ${ }^{102}$.

El Diario de Madrid, que también gozaba de una difusión apreciable, multiplicó a ritmo acompasado y hasta finales del año las referencias al drama. Varios fueron los artículos (en este caso breves, al componerse cada número de sólo cuatro páginas) que publicó al respecto ${ }^{103}$. Al igual que los memorialistas, los diaristas ofrecieron a sus lectores una crónica del drama y reprodujeron íntegramente todos los textos oficiales relativos al acontecimiento. Pero

$101 \quad$ Ibid., pág. 75.

102 Elisabel LaRriba, «De l'usage de la gravure dans le Memorial literario (1784-1808)», en El Argonauta espagnol. Revue bilingue, franco-espagnole consacrée à l'étude de la presse espagnole de ses origines à nos jours (XVII-XXI siècles), núm. 5 (enero de 2008), 〈http://argonauta.imageson.org〉.

103 «Noticias particulares de Madrid», en Diario de Madrid, 19 de agosto de 1790 (núm. 231), págs. 925-926; «Noticia del incendio de la plaza Mayor», en id., 20 de agosto de 1790 (núm. 232), págs. 927-928, y en el mismo número, «Noticias particulares de Madrid», págs. 928-929; «Continuación de las noticias del incendio», en id., 21 de agosto de 1790 (núm. 233), págs. 931-932; «Bando», en id., 22 de agosto de 1790 (núm. 234), págs. 935-937; «Continuación de las noticias del incendio», en id., 24 de agosto de 1790 (núm. 236), págs. 943-947; «Aviso al público», en id., 25 de agosto de 1790 (núm. 237), págs. 952-953; «Continúa la noticia del incendio de la plaza Mayor», en id., 26 de agosto de 1790, págs. 957-958; «Noticias particulares de Madrid», en id., 28 de agosto de 1790 (núm. 240), págs. 965-966; «Continúan las noticias del incendio», en id., 29 de agosto de 1790 (núm. 241), págs. 967-969; «Heroica resolución de dos militares en la extinción peligrosa de unos maderos incendiados en el fuego de la plaza Mayor», en id., 30 de agosto de 1790 (núm. 242), págs. 971-973; «Noticias particulares de Madrid», en id., 5 de septiembre de 1790 (núm. 248), pág. 996; «Aviso al público», en id., 10 de septiembre de 1790 (núm. 253), págs. 1016-1017; «Señor Diarista», en id., 18 de septiembre de 1790 (núm. 261), págs. 1047-1048; «Respuesta del Diarista a la carta inserta en el Diario de ayer», en id., 19 de septiembre de 1790 (núm. 262), págs. 1051-1054; «Bando», en id., 22 de octubre de 1790 (núm. 295), págs. 1183-1186; «Noticias particulares de Madrid», en id., 28 de octubre de 1790 (núm. 301), págs. 1209-1210; «Bando», en id., 9 de noviembre de 1790 (núm. 313), págs. 1255-1258; «Noticias particulares de Madrid», en id., 12 de noviembre de 1790 (núm. 315), págs. 1464-1465; Carta a los diaristas (sin título), en id., 16 de noviembre de 1790 (núm. 320), págs. 1283-1284; «Aviso», en id., 23 de noviembre de 1790 (núm. 327), págs. 1312-1313; Carta a los diaristas (sin título), en id., 6 de diciembre de 1790 (núm. 340), págs. 1363-1364; «Aviso al público», en id., 21 de abril de 1791 (núm. 111), págs. 451-452. 
el Diario también abrió las páginas de su famosa rúbrica Noticias particulares de Madrid (dedicada a anuncios de toda índole) a las víctimas del incendio. De hecho, varias personas acudieron al periódico con la esperanza, mediante un aviso milagroso, de recuperar tal o cual objeto perdido. Pero también hubo vecinos que se valieron del periódico para dar cuenta de las pertenencias que se habían encontrado entre los escombros de la plaza. Los primeros avisos al respecto se insertaron en el número del 23 de agosto, fecha en que todos los anuncios de la sección Pérdidas (o sea cinco) estaban relacionados con el incendio. En el primero se daba a conocer que «por la confusión de la noche y mañana de los días 16 y 17 se recogieron por equivocación» dos baúles y se extravió otro «forrado en badana encarnada bien tratado, y con dos cifras de María a los dos lados de una cerradura que ten[ía]» ${ }^{104}$. En el segundo se informaba que «la noche del fuego se perdieron, llevando ropa, tres sábanas nuevas de Coruña, y una basquiña de sarga negra» ${ }^{105}$. En el tercero se hizo saber que

en la noche del 16 del corriente se extraviaron al tiempo de sacar los muebles de las casas incendiadas en la calle de Toledo, un libro en folio empergaminado, con su rótulo que de[cía] entre otras cosas: Títulos de una casa calle del Almendro, pertenecientes a D. Matías Sánchez de Tagle... ${ }^{106}$.

El comerciante Antonio Pérez Cabezón comunicaba haber perdido, esa misma noche, una partida de géneros que consistía en

[...] paquetes de medias de algodón de varias clases, hilos de dos clases en paquetes, una caja de hoja de lata que incluye en ella varios hilos en madejas, otra caja también de hoja de lata con varios bolsillos y evangelios bordados de plata falsa, otra caja de cartón con diferentes botones de hilo, un paquete de cordones de seda, y otros géneros... ${ }^{107}$.

Otra persona deseaba hallar el paradero de «un cofre que se perdió en la noche del Lunes 16 con el motivo del fuego, que le llevó un soldado a un montón de ropa, que es de pellejo, con 5 varas de palo, algo maltratado, con la cerradura floja...» ${ }^{108}$.

\footnotetext{
104 Diario de Madrid, 23 de agosto de 1790 (núm. 235), pág. 940.

105 Id.

106 Ibid., págs. 940-941.

107 Ibid., pág. 941.

108 Id.
} 
Los treinta anuncios de esa misma índole que se publicaron entre el 23 de agosto de 1790 y el 24 de febrero de 1791 en las rúbricas Pérdidas y Hallazgos ${ }^{109}$ del Diario nos permiten apreciar la tremenda confusión que se apoderó de la plaza en llamas, cuyos vecinos para salvar sus bienes no dudaron en arrojar cuanto podían por las ventanas. Tal fue el caso de D. Ignacio Martínez quien, a los seis meses de estallar el incendio, acudió en última instancia al Diario informando que

[...] con motivo del incendio acaecido en la plaza Mayor el 16 de Agosto de 1790, entre los muebles que se tiraron por los balcones, se han extraviado varios papeles, y entre ellos una Escritura de la compra de media casa, el testamento, el capital, y una escritura de imposición contra la Renta del tabaco al 7 por ciento: todos estos instrumentos [agregaba] están a favor de D. Ignacio Martínez; cualesquiera persona que sepa su paradero, se servirá acudir a casa de dicho Martínez, que vive plaza mayor portal de torneros a el lado del cabecero del Rey ${ }^{110}$.

De todo hallamos en el inventario que nos ofrecen esos anuncios: muebles, cuadros, «un espejo de poco valor» ${ }^{111}$, el espadín con puño de plata de un niño ${ }^{112}$, libros, ropa (de vestir, de cama, de mesa...), alhajas, dinero, documentos de todo tipo (vales reales, acciones, recibos de casa, cartas de dote, relaciones de méritos...) y hasta un «pedazo de tocino» ${ }^{113}$. Objetos de poca monta, pero también

109 Diario de Madrid, 23 de agosto de 1790 (núm. 235), págs. 940-941; 24 de agosto de 1790 (núm. 236), pág. 949; 28 de agosto de 1790 (núm. 240), págs. 968-969; 31 de agosto de 1790 (núm. 243), págs. 977-978; 2 de septiembre de 1790 (núm. 245), pág. 985; 4 de septiembre de 1790 (núm. 247), pág. $993 ; 5$ de septiembre de 1790 (núm. 248), pág. 996; 7 de septiembre de 1790 (núm. 250), pág. 1006; 12 de septiembre de 1790 (núm. 255), pág. 1026; 13 de septiembre de 1790 (núm. 256), pág. 1030; 14 de septiembre de 1790 (núm. 257), pág. 1033; 16 de septiembre de 1790 (núm. 259), pág. 1042; 17 de septiembre de 1790 (núm. 260), pág. 1045; 18 de septiembre de 1790 (núm. 261), pág. 1049; 23 de septiembre de 1790 (núm. 266), pág. 1066; 24 de septiembre de 1790 (núm. 267); 25 de septiembre de 1790 (núm. 268), pág. 1077; 3 de octubre de 1790 (núm. 276), pág. 1109; 7 de octubre de 1790 (núm. 280), pág. 1125; 8 de octubre de 1790 (núm. 281), pág. 1130; 9 de octubre de 1790 (núm. 282), pág. 1134; 13 de octubre de 1790 (núm. 286), págs. 1149-1150; 14 de octubre de 1790 (núm. 287), pág. 1154; 18 de octubre de 1790 (núm. 291), pág. 1170; 23 de octubre de 1790 (núm. 296), pág. 1189; 24 de febrero de 1791 (núm. 55), pág. 230.

110 Diario de Madrid, 24 de febrero de 1791 (núm. 55), pág. 230.

111 Diario de Madrid, 12 de septiembre de 1790 (núm. 255), pág. 1026: «Hallazgo. A quien se le hubiera extraviado en la noche del incendio un fardo, que contiene una colgadura de cama acudirá al R. P. Fr. Manuel de Arriba, Trinitario Calzado a quien dando las señas lo entregará; también tiene un espejo de poco valor, cuyo dueño le ignora».

112 Diario de Madrid, 28 de agosto de 1790 (núm. 240), págs. 968-968: «Pérdidas. Quien hubiere hallado un espadín con puño de plata, que se perdió en la noche del día 16 con motivo del incendio a un niño desde la esquina de la calle de la Amargura, hasta S. Felipe Neri, acuda a la librería de D. Antonio Romeral, calle de Barrio-Nuevo, quien dará señas y hallazgo».

113 Diario de Madrid, 2 de septiembre de 1790 (núm. 245), pág. 985: «Pérdidas. Quien hubiese perdido algún pedazo de tocino, que con motivo del incendio ocurrido en el portal de Paños en la noche del 16 pasado, 
del mayor valor. Así, al recorrer las páginas del Diario se descubre, por ejemplo, que en la noche del 16 de agosto «se tiró por un balcón de la calle de Toledo, sin advertir lo que era, tres aderezos de diamantes en una cajita» y que quien la hubiese hallado la podía «entregar a D. Juan Antonio Barbado de la Torre en los claustros de S. Isidro, quien dar[í]a las señas y el hallazgo» ${ }^{114}$ o que

[...] con motivo del incendio acaecido en la noche del día 16 de Agosto, se extraviaron de un escritorio de Salamanca, que se hallaba abierto, mil y ochocientos rs. en varias monedas de plata y oro, como asimismo dos cajas de plata hechura de Inglaterra, y otra de nácar con la historia de Susana,

cuyo propietario esperaba recuperar con la promesa de «un buen hallazgo» ${ }^{115}$.

Pero también, lo que puede parecer más sorprendente, se insertaron avisos relacionados con el drama en la rúbrica «Fiestas». Así, el 4 de septiembre se podía leer lo siguiente en el Diario:

El Clero y varios feligreses de la Iglesia de S. ${ }^{\text {ta }}$ Cruz que vivían en las manzanas y calles próximas al incendio, reconocidos del singular beneficio que han recibido de Dios, en no haberse extendido el fuego a sus habitaciones, consagran agradecidos y tributan debidos cultos al Todo Poderoso, expuesto por todo el día el santísimo Sacramento con Misa solemne, Sermón, Te Deum y Completas, mañana Domingo a las 10 de su mañana. Predicará el P. D. Cayetano Torneo de los Ríos, Clérigo reglar, teólogo, consultor de la Cámara, y Examinador de la Sacra Asamblea, y de la Nunciatura de España, Predicador de S. M. en su Real Casa de S. Cayetano de esta Corte. Asistirá a Misa, Te Deum, y Completas un concierto de voces ${ }^{116}$.

Menos egoístas o más compasivos ante el dolor ajeno fueron los habitantes de la calle Cuchilleros y de las dos manzanas vecinas, según consta en el anuncio publicado el 10 de octubre. Al igual que sus antecesores organizaron los debidos cultos para dar gracias a Dios de haber «apaciguado el fatal incendió que les amenazó». Pero no se olvidaron de quienes tuvieron menos suerte que ellos y costearon a la par en la Iglesia de San Salvador una misa cantada con vigilia y

se recogió con otros varios muebles en la plaza Mayor, acuda a la calle de Ileras casa n. ${ }^{\circ} 8$, qto. principal, que dando las señas individuales se entregará».

114 Diario de Madrid, 31 de agosto de 1790 (núm. 243), pág. 978.

115 Id.: «La persona que supiese su paradero, acudirá para su entrega al P. Joseph de la Hedesa, de los Agonizantes de la calle de Atocha, quien dará un buen hallazgo».

116 Diario de Madrid, 4 de septiembre de 1790 (núm. 247), pág. 997. 
responso por las almas de los fallecidos en el incendio ${ }^{117}$, sobre los que tanto el Diario de Madrid como el Memorial literario corrieron un tupido velo.

Si exceptuamos este anuncio, la única referencia explícita a la muerte (que no faltó al encuentro) la hallamos en el Diario del 24 de agosto donde se indica que, tras perecer un obrero en el derrumbamiento de un piso cercano del Arco de Toledo, las autoridades dieron órdenes inmediatas para que los arquitectos y maestros de obras reconocieran los edificios y se evitaran en adelante semejantes desgracias, como lo exigía «la buena policía y la humanidad» ${ }^{118}$.

El incendio que estalló en plena noche y se extendió con una increíble celeridad, como recalcó el articulista de La Espigadera, «separó los cuerpos de las almas» ${ }^{119}$. Sin embargo, los memorialistas y los diaristas se limitaron a evocar púdicamente la miseria y la desesperanza de las víctimas, en proporcionar el número de casas destruidas y de desalojados. Olvidándose de las flaquezas humanas, prefirieron destacar la solidaridad de los madrileños, el heroísmo de quienes combatieron el fuego, así como el celo y la eficacia de las autoridades. Brindaron a sus lectores una crónica pormenorizada del incendio y no pocas informaciones del mayor interés para quienes se vieron directamente afectados por el drama, las más de ellas comunicadas por las autoridades que vieron en la prensa un auxiliar eficaz, una idónea correa de transmisión de las medidas que iban tomando, una perfecta vitrina de su dedicación al bien público. De hecho, la visión que los publicistas ofrecieron del drama, amenizada y patriótica, carente de la menor crítica, sufrió del prisma deformador de la verdad oficial que, sin embargo, ningún efecto tuvo sobre la pluma del «Extranjero» cuyas observaciones divulgó La Espigadera.

117 Diario de Madrid, 10 de octubre de 1790 (núm. 283), pág. 1138: «Fiesta. Rendidos Cultos que al Santísimo Sacramento, y al glorioso Arcángel S. Miguel, se celebran hoy en la Iglesia Parroquial de S. Salvador de esta Corte, a expensas de sus devotos Parroquianos habitantes de la calle de Cuchilleros y contornos de sus dos manzanas, agradecidos al singular favor del Todo Poderoso en haberlos favorecido en que se apaciguase el fatal incendio que les amenazó. Estará patente el Santísimo Sacramento por mañana y tarde, y predicará el P. D. Cayetano Torneo de los Ríos, Clérigo reglar y Predicador de S. M. en su Real Casa de S. Cayetano de esta Corte. Asistirán a la Misa y por la tarde a las Completas y Te Deum (que serán concluidos los ejercicios de dicha Iglesia) un concierto de voces e instrumentos; y mañana a las 10 se celebra en la referida Iglesia Misa cantada con Vigilia y Responso, aplicándolo por las Almas de los que han fallecido a causa de este incendio».

118 Diario de Madrid, 24 de agosto de 1790 (núm. 236), pág. 943: «[...] Habiendo dado cuenta el Alcalde D. Pedro Carrasco al Sr. Gobernador del Consejo, del fracaso de hundirse el piso de una casa cercana al arco de Toledo en la tarde del día 22 con cuatro trabajadores de los cuales se salvaron tres, y pereció uno; comunicó en el propio día su Excelencia a la Sala, y al Corregidor de Madrid las órdenes más estrechas a fin de que cuidasen de asegurar a los trabajadores por medio de reconocimientos previos que deberían hacer los Arquitectos, y maestros de Obras, a cuyo cargo corriesen estas operaciones para evitar de antemano semejantes desgracias, como lo exige la buena policía y la humanidad».

119 «Carta irónica de un Extranjero a un Paisano, en que le participa algunas observaciones hechas por sí mismo, durante el fuego acaecido en la plaza Mayor de esta Corte el 16 de agosto de este año de 1790», en La Espigadera, tomo I, núm. 1, pág. 35. 
Este, enarbolando la bandera de la ironía, se adentró con arrojo por los senderos oscuros que el Memorial literario y el Diario de Madrid se negaron en explorar. Su diferencia la afirmó nada más iniciar su relato:

No me detengo a referir por menor la combinación de fatales circunstancias, que tanto contribuyeron a su incremento [el del incendio], y progresos, ni el conjunto de calamidades ocurridas así en las personas como en los intereses. De todo esto supongo a vmd. ya perfectamente instruido por otros papeles, que circularon inmediatamente así dentro, como fuera del Reino. Yo me limito a ciertas brevísimas observaciones hechas sobre los mismos hechos en que intervine como testigo ocular, porque como no tengo ocupación fija, me hallaba en todo, y de esta clase de personas está inundada la Corte ${ }^{120}$.

Sus ojos sagaces y censores se detuvieron en las menudencias que poco contribuían al lustre de la masa humana que en un santiamén invadió la plaza, atraída irresistiblemente por «el estruendo y estrépito tumultuario de las campanas, la gritería del paisanaje azorado, los tambores de los Soldados, los sollozos y lamentos de los miserables que naufragaban en aquel voracísimo incendio» ${ }^{121}$. Toda la plaza estaba llena, y muy llena de gente que carecía de los instrumentos necesarios para combatir el fuego. Pero huelga decir, subrayaba, que «si esta clase de gentes, a quienes devoraba un celo nada común, se hubieran hallado provistos, hubieran hecho mucho menos daño que los empleados y destinados por el estado» ${ }^{122}$. Pero como pudo comprobar, lejos de permanecer inactivos estos celosos patriotas (que no faltan en la historia de los incendios), animados por una «caridad heroica», «saltaron por donde pudieron, abriéndose paso por aquel inmenso tropel de mirones» ${ }^{123}$ para salvar los metales ajenos. También le llamaron la atención los corrillos que se iban formando, fuente inagotable de conversaciones muy a menudo eruditas, que era indudablemente lo que «hacía más falta en aquel lance» ${ }^{124}$. Y mientras el fuego iba cobrando fuerza y arrebataba vidas, los concurrentes disputaban sobre las teorías de los mayores científicos y se deshacían en elaborar proyectos que otros (más sensatos, a no ser que menos patrióticos) daban por «quiméricos e impracticables» ${ }^{125}$. De todo ello brotaron algunas «oportunas diligencias», pero que «se suspendieron sin duda para cuando suceda (lo que

\footnotetext{
$120 \quad$ Ibid., págs. 28-29.

121 Ibid., pág. 32.

122 Ibid., págs. 32-33.

123 Ibid., pág. 33.

124 Ibid., pág. 34.

125 Ibid., pág. 35.
} 
Dios no permita) otro fuego en la plaza» ${ }^{126}$. Tampoco faltaron las referencias a «algunos cortesanos sensatos, aquellos hombres destinados a pensar, sujetos de peso y asiento, y que no pierden su serenidad por nada en este Mundo, ni se moverán a echar una mano, aunque vieran arder toda la plaza Mayor» ${ }^{127}$, a cuantos opinaban que si «desde el principio se hubiera tomado una mediana providencia» el drama no hubiera cobrado tamañas dimensiones. Nuestro sagaz observador no estaba lejos de pensar que «se hubiera verificado su predicción si todos hubieran acudido a la causa común como estos bellos Ciudadanos, y hubieran dado pruebas evidentes de su energía, actividad y celo» ${ }^{128}$. Demasiado «críticos y pensadores» eran, declaró con una buena pincelada de sorna, quienes vislumbraban una

terrible contradicción entre el fervor y actividad con que se pretende fomentar el patriotismo en el escrito, (pues ninguno vale como no reviente patriotismo por todos sus poros) y el manifiesto abandono que se advierte por el bien común llegando el caso de hacerlo patente ${ }^{129}$.

Esta era otra visión, más cruda y desilusionada, de una misma realidad, la faz sombría de un drama cuya resonancia rebasó ampliamente los límites de la capital, como recalcó con toda razón nuestro cínico extranjero.

No olvidemos que, gracias al sistema de la venta por suscripción, las tres cabeceras que acabamos de mentar, y con ellas varios periódicos madrileños, gozaban de cierta difusión fuera de la Corte y hasta en lugares remotos de la Península ${ }^{130}$. Pero la prensa de provincias también se interesó por el asunto. Así, el Diario de Valencia informó con la mayor rapidez a sus lectores sobre el drama que padecieron los madrileños. El 24 de agosto les ofreció la «Noticia del incendio acaecido en la plaza Mayor de Madrid» ${ }^{131}$, que dio lugar a varias entregas con fecha del 31 de agosto, 4 y 5 de septiembre de 1790. Los cuatro textos propuestos, meramente informativos, procedían todos de artículos del Diario de de Madrid que los editores valentinos reprodujeron con la mayor fidelidad y no poca celeridad ${ }^{132}$. El único toque original que se autorizaron estribó en la

126 Ibid., págs. 35-36.

127 Ibid., pág. 29.

128 Ibid., pág. 30.

129 Ibid., págs. 30-31.

130 Elisabel Larriba, Le Public de la presse en Espagne à la fin du XVIII siècle (1781-1808), op. cit.

131 Diario de Valencia, 24 de agosto de 1790 (núm. 55), págs. 218-219.

132 «Noticia del incendio acaecido en la plaza Mayor de Madrid», en Diario de Valencia, 24 de agosto de 1790 (núm. 55), págs. 218-219 (copiado del Diario de Madrid, 20 de agosto de 1790 (núm. 232), págs. 927 928); «Continuación de las noticias del incendio de Madrid. Día 26 del corriente», en Diario de Valencia, 31 de agosto de 1790 (núm. 62), págs. 246-247 (copiado del Diario de Madrid, 26 de agosto de 1790 (núm. 238), págs. 957-958); «Continuación de las noticias del incendio de la plaza Mayor de Madrid», en Diario de 
publicación el 30 de agosto de un soneto, Al incendio acaecido en la plaza Mayor de Madrid, tema que fue aprovechado para loar la generosidad de los reyes. El poema no destaca por su calidad, pero su presencia entre las páginas del Diario de Valencia es prueba del gran interés que suscitó el acontecimiento.

La Corte del Gran Carlos incendiada;

Su corazón piadoso consternado,

La que es toda dulzura, todo agrado,

Luisa De Borbón sobresaltada:

De su amor paternal no admiro nada,

Al mirar a su Pueblo atribulado,

Con profusión caudales han librado

Para la gente más necesitada.

¡Oh! quiera el Cielo conservar su vida

De tan dignos Monarcas muchos años,

Para que a España a ambos sometida

Le eviten males, y remedien daños,

$\mathrm{Y}$ de sus Enemigos defendida,

Impidan la dominen los Extraños.

D. J. M. C. D. J.

V.2. El incendio fuente de inspiración y ganancias para los grabadores

$\mathrm{Y}$ tal fue el impacto causado por el drama que a las pocas semanas de declararse el fuego salieron a la venta varios grabados en que se podía apreciar la magnitud del desastre. El 31 de agosto la Gaceta de Madrid daba a conocer que en la librería de Escribano (frente a la Imprenta Real) y en el mismo puesto de la Gaceta (en la calle de Toledo) se hallaría un Plan de la plaza Mayor de Madrid, en que se manifiesta la parte que se quemó de resultas del incendio... completado por «una breve razón de esta desgracia, y una noticia histórica de la construcción de la plaza, y de los incendios que padeció anteriormente». Se precisaba a la par que se podía «remitir en carta, y colocarse con su explicación a modo de mapa con medias cañas o en marcos» ${ }^{133}$. A los pocos días, el 7 de septiembre, se anunciaba la

Valencia, 4 de septiembre de 1790 (núm. 66), págs. 262-263 (copiado del Diario de Madrid, 29 de agosto de 1790 (núm. 241), págs. 967-968); «Continuación de las noticias del incendio de la plaza Mayor de Madrid», en Diario de Valencia, 5 de septiembre de 1790 (núm. 67), págs. 266-268 (copiado del Diario de Madrid, 30 de agosto de 1790, núm. 242, págs. 971-972).

133 Gaceta de Madrid, 31 de agosto de 1790 (núm. 70), pág. 582. Lo más probable es que se trate del plano insertado en el Memorial literario de agosto de 1790, op. cit. 
Vista de las ruinas de la plaza Mayor causadas por el incendio de la noche del 16 de Agosto de este año, en una estampa de medio pliego de marca, en la que con su explicación al pie y exactamente copiados se señalan con números los principales edificios y ruinas de dicha plaza.

El grabado a la venta en Madrid, en la librería de Quiroga (calle de la Concepción) también se podía adquirir en Sevilla (librería de Caro), en Valencia (imprenta de Orgas) y en Barcelona (librería de la Viuda de Piferrer) ${ }^{134}$. Ese mismo día el Diario de Madrid mentó una «Lámina nueva que representa la vista del lastimoso incendio acaecido en dicha plaza» propuesta a un real en la tienda de Escribano ${ }^{135}$. El 10 de septiembre la Gaceta informaba a sus lectores que en esa misma librería, en el puesto del Diario de Madrid y en Cádiz (en la casa de Savid) se vendía por dos reales otro grabado que representaba «La vista de la plaza Mayor de Madrid al tiempo de manifestarse el fuego en la noche de 16 de Agosto de este año; y de los estragos que hizo el primer día» ${ }^{136}$. Como consta en el Diario de Madrid del 15 de septiembre, en la librería de Escribano también se podía comprar un «Plano que representa la ruina causada en la plaza Mayor por el incendio del día 16 de Agosto, y estado en que se halla en el día» ${ }^{137}$. El 16 de septiembre se anunció la venta de otra lámina que incluía una hermosa «Vista de la ruina causada por el incendio...» (dibujada por S. Pérez y grabada por F. Marti) y la «Planta de la plaza Mayor y sus inmediaciones» con «escala de pies castellanos para poder medir con exactitud lo arruinado» ${ }^{138}$. La «Estampa de la vista del incendio de la plaza Mayor de Madrid entre 2 y 3 de la noche del 16 de agosto» mentada en el Diario el 26 de octubre se podía adquirir en tres librerías de la capital (las de Escribano, de la viuda de Sánchez y de Bartolomé López) así como en Cádiz (en la de Victoriano Pajares), en Zaragoza (en la de Juan Ibáñez, impresor) y en Málaga (en casa de Joseph Fariñas) ${ }^{139}$... Notemos

134 Gaceta de Madrid, 7 de septiembre de 1790 (núm. 72), pág. 598. También se anunció ese mismo día en el Diario de Madrid (núm. 250), pág. 1005. Se conserva un ejemplar de este grabado en la BNM (Inv. Est. núm. 14.882).

135 Diario de Madrid, 7 de septiembre de 1790 (núm. 250), pág. 1006. Se conserva un ejemplar de este grabado en la BNM (Inv. Est. núm. 14.879).

136 Gaceta de Madrid, 10 de septiembre de 1790 (núm. 73), pág. 606. Se conserva un ejemplar de este grabado en la BNM (Inv. Est. núm. 14.870).

137 Diario de Madrid, 15 de septiembre de 1790 (núm. 258), pág. 1037.

138 Diario de Madrid, 16 de septiembre de 1790 (núm. 259), pág. 1041: «Vista de la ruina causada por el incendio de la plaza Mayor, y la planta de dicha plaza, y sus inmediaciones con la escala de pies castellanos para poder medir con exactitud lo arruinado, y demás que contiene la planta; se hallará en la calle de Carretas en la librería de Escribano, y en la calle de Atocha en casa de Razola». Se conserva un ejemplar de este grabado en la BNM (Inv. Est. núm. 14.871).

139 Diario de Madrid, 26 de octubre de 1790 (núm. 299), págs. 1201-1202. 
a la par que varios de estos anuncios también se publicaron en la Gaceta de Barcelona $^{140}$.

Como evidencia este nutrido botón de muestra el acontecimiento que durante semanas y hasta meses cautivó a los madrileños adquiría paulatinamente una resonancia nacional. A ritmo acompasado fueron apareciendo grabados que permitían apreciar, descubrir o recordar visualmente las diferentes fases del incendio, los estragos causados por el fuego, la labor de quienes participaron a su extinción... Algunas de esas estampas, anónimas las más, eran de calidad mediocre. Pero también se interesaron por el asunto grabadores de valor reconocido como el valenciano José Jimeno Carrera, de cuyo buril nació (según reza el anuncio publicado en la Gaceta de Madrid del 14 de septiembre) una «estampa iluminada en medio pliego de papel imperial de Holanda, que representa la vista que ofrecía el incendio de la plaza mayor de Madrid la noche del día 16 de agosto...». Se vendía en tres librerías de la capital, la de Luna (red de San Luis), la de Castillo (frente a San Felipe) y la de Escribano (calle de Carretas $)^{141}$. Obviamente ya no se trataba exclusivamente de informar o saciar la curiosidad de un público popular, sino de seducir a una clientela selecta y adinerada aficionada a los grabados. La catástrofe por su magnitud había suscitado una fuerte emoción que no era privativa de ninguna clase social y que no se paró en los límites de la capital. El drama se había convertido en espectáculo y hacía vender hasta tal punto que en enero de 1791 (casi a los seis meses de declararse el incendio) salió al mercado una nueva estampa que permitía valorar «el estado en que dejó el fuego a la plaza Mayor de Madrid» y era «compañera de las anunciadas anteriormente» en el Diario de Madrid, pudiéndose adquirir en Madrid en las librerías de Luna y de Escribano, así como en Cádiz (en la de Pajares) $)^{142}$.

\section{Del drama a la reflexión sobre el modo de limitar los riesgos}

\section{VI.1. Un repentino y fugaz interés por las compañías de seguros}

El temor inducido por el drama también abrió inauditas perspectivas a las compañías de seguros. Como recalcó el bachiller Pedro Gatell, a sabiendas de

\footnotetext{
140 Vid. por ejemplo la Gazeta de Barcelona del 7 de septiembre (núm. 72), pág. 596, del 14 de septiembre de 1790 (núm. 74), pág. 612, o del 21 de septiembre de 1790 (núm. 76), pág. 628.

${ }^{141}$ Gaceta de Madrid, 14 de septiembre de 1790 (núm. 74), pág. 606. Se conserva un ejemplar de este grabado en la BNM (Inv. Est. núm. 14.873).

142 Diario de Madrid, 4 de enero de 1790 (núm. 4), pág. 15. Trátase probablemente de la Vista de la plaza Mayor de Madrid en el estado que la dejó el fuego (BNM, Inv. Est. núm. 14.874).
} 
lo ocurrido en Madrid, en el periódico gaditano titulado El Argonauta español, que salió a luz en 1790:

Un caudal de millares de pesos queda arruinado después de un incendio. El que tiene hoy muchas posesiones queda mañana mendigando por el fuego. El que tiene sólo la casa en que vive, se ve en la calle; y lo que es más doloroso, es el ver que ya ocurre al socorro el Real erario. Ya es casi forzoso que todos contribuyan para la reedificación del edificio abrasado ${ }^{143}$.

¿Cómo evitar semejante desgracia? Acudiendo a las compañías de seguros que el autor presentaba, según rezaba el título del artículo, como un «magnífico remedio para preservar las ruinas que ocasionan los incendios» y que en Londres (donde ya constituían un recurso manoseado) aseguraban, decía, hasta las vidas. El Argonauta que no tenía «ni casa, ni hogar», esperaba sin embargo con ansia que semejantes instituciones se crearan con la mayor brevedad en España y que cuantos poseyeran casas acudieran a ellas sin la menor reserva, en su propio beneficio, y en el del erario real ${ }^{144}$.

Huelga decir que las enormes pérdidas provocadas por el incendio de la plaza Mayor convirtieron el desarrollo de semejantes organismos en un tema de candente actualidad. El efecto fue inmediato. El 25 de agosto de 1790 el Diario de Madrid informaba a sus lectores de la publicación (tras consulta de la Junta General de Comercio y Moneda y con la aprobación del rey) de las ordenanzas de una compañía de seguros terrestres y marítimos establecida en el número seis de la Corredera de San Pedro. Y los anunciantes no omitieron indicar que el referido texto, en venta en la librería de la viuda de Ibarra, incluía «el papel de las Prevenciones que deberán tener presentes los que quieran asegurar de incendio casas, efectos y muebles» así como las tablas de precios ${ }^{145}$. Nada más

143 El Argonauta español, periódico gaditano en el que se corrigen por un estilo jocoso los actuales abusos en todas clases de materias, y al mismo tiempo se suministran pensamientos interesantes a el mayor progreso de las Ciencias, Artes, Agricultura, y comercio, e igualmente noticias curiosas, anécdotas \&c. Obra útil, deleitable, e instructiva a todas las personas de ambos sexos, Cádiz, Imprenta de Murguía, 1790, núm. 21, pág. 165 (pág. 233 de la edición que publicamos en el Servicio de Publicaciones de la Universidad de Cádiz, 2003).

144 Ibid., pág. 166 (pág. 234 de nuestra edición): «Animado de la verdad de este pensamiento, y lo que es más, de las infinitas utilidades que resultan, espera el Argonauta que con la mayor brevedad veremos en España erigidas Compañías donde por un desembolso poco considerable se aseguren los valores de las casas, y al propio tiempo correr a los que las tengan para lograr este beneficio. / El Argonauta no tiene casa ni hogar; no obstante desea se establezca una casa tan interesante a los que las tengan. / Asimismo aconseja a los que tengan posesiones, esto es, casas, o haciendas con inmediación a los ríos, que ocurran a dichas Compañías futuras de Seguros, pues se han visto un sinnúmero de estragos y pérdidas considerables, algunas irremediables, por una total destrucción de los edificios, y ruina de todo lo demás».

145 Diario de Madrid, 25 de agosto de 1790 (núm. 237), pág. 954. 
publicado el aviso, varios madrileños acudieron a las oficinas de la aseguradora para obtener más informaciones. Con lo cual la dirección de la Compañía se apresuró en comunicar a los diaristas una nota explicativa relativa al cálculo de las cuotas, ofreciendo para mayor claridad a los lectores del periódico (todos clientes potenciales) «una demostración», o sea un ejemplo concreto que sirviera de base para determinar el monto exacto de las pólizas, que variaba en función del tipo de construcción, del valor de la casa, de su antigüedad y también del oficio desempeñado por sus ocupantes:

Un edificio fabricado de piedra de sillería, mampostería, o ladrillo, embovedado, cubierto de teja, pizarra o plomo, y habitado por familia, o familias, que no ejerzan arte, u oficio, cuyas operaciones expongan a incendio, lo asegura la Compañía por un año a razón de medio a tres cuartillos por mil según el más o menos tiempo que esté construido, de suerte que una casa de la referida especie valga quinientos mil rs. de vn. de que sólo asegura la Compañía las cuatro quintas partes, que son cuatrocientos mil rs. de vn. costaría el seguro de estos a su dueño, a razón de medio por mil, doscientos rs. de vn. cada año, de que aun podría reintegrarse con el beneficio que podrán dar «las acciones si hipotecara la misma casa para tomar algunas de las de esta clase ${ }^{146}$.

Asimismo, los 17 y 18 de octubre los diaristas publicaron una extensa carta que les había remitido un asiduo lector cuya identidad no desvelaron ${ }^{147}$. Este declaraba haber oído a varios conciudadanos suyos mofarse de la Real Compañía de Seguros Terrestres y Marítimos recientemente establecida que, según ellos, hubiera quebrado de asegurar las casas incendiadas. Acicateada su curiosidad y deseoso de verificar la validez de tan rotunda afirmación, el anónimo corresponsal, había comprado las ordenanzas y el papel de prevenciones publicadas por dicho organismo. Las había estudiado con el mayor detenimiento y había profundizado el tema discutiendo con personas que habían viajado a capitales europeas donde ya existían, para beneficio del público, cuerpos similares. Ante la novedad que tales compañías constituían para sus compatriotas juzgó útil, antes de librar el fruto de sus reflexiones y cálculos, incidir en los mecanismos básicos que regían su actividad:

La base fundamental [subrayó] de la prosperidad de los establecimientos de esta naturaleza pende principalmente de la multiplicidad de riesgos que tome, para que

146 Diario de Madrid, 9 de septiembre de 1790 (núm. 252), pág. 1014.

147 «Señores Diaristas», en Diario de Madrid, 18 de octubre de 1790 (núm. 291), págs. 1163-1164, y «Fin de la Carta de ayer», en id., 19 de octubre de 1790 (núm. 292), págs. 1167-1169. 
el fruto de la felicidad con que, según observaciones, se sale de casi todos, resarza los daños de la adversidad de algunos que se desgracian, sin cuya proporción será casual su subsistencia, al paso que con ella (¡raro fenómeno!) no se puede dudar que adquiere en el mayor número de riesgos, muchos más grados de probabilidad, que otra cualquier operación mercantil, en punto a la seguridad de las favorables resultas de sus empresas.

No sólo asegura esta Compañía los edificios y casas del incendio, sino también sus muebles, menaje y almacenes de todos géneros; pero prescribe que no se pueda exceder de las cuatro quintas partes de su valor, con la mira, sin duda, de que no descuiden absolutamente los dueños de su conservación, y aun de precaver los maliciosos incendios a que pudiera estimular las mayores ventajas que presente la seguridad de la percepción de su total importe ${ }^{148}$.

Tras estas aclaraciones, el corresponsal del Diario se libró a dos «demostraciones» matemáticas. La primera (con indicación del importe de las pólizas en función del tipo de casa asegurada) iba destinada a evidenciar «la excesiva poquedad con que pueden conseguir los dueños el descanso y descuido del mayor de los riesgos que amenazan sus edificios» ${ }^{149}$. La segunda estribaba en una estimación pormenorizada de las ganancias que la compañía realizaría si los propietarios de un $40 \%$ de las casas madrileñas (tres mil de un total de 7.500) vencieran su aprehensión respecto a semejantes organismos. Según sus cálculos el importe anual a favor de la compañía sería de 1.488 .000 reales. Y agregaba que, aunque ocurrieran dieciocho incendios al año en Madrid («que ordinariamente no acontecen»), todavía le quedarían libres a la compañía 1.368.000 reales y que en veinte años de existencia sus caudales, tras descuento de las indemnizaciones, serían de 26.688 .000 reales. Asimismo, para «disipar enteramente los vanos temores que ha[bía] infundido en algunas gentes el fuego de la plaza», recalcó que semejantes catástrofes eran muy excepcionales y que habían cursado ciento diecisiete años desde la quema de la Panadería. Y se lanzó en nuevos cálculos destinados a demostrar que la aseguradora madrileña hubiera podido hacer frente sin el menor problema a las pérdidas generadas por el incendio de la plaza Mayor. De haber estado aseguradas las cincuenta y dos casas destruidas (lo que era muy improbable) y siendo el valor medio de cada una de cien mil reales (estimación harto generosa según el parecer de los arquitectos), las pérdidas, afirmaba, hubieran ascendido a un total de 5.200.000 reales que rebajados de los 26.688.000 ya mentados hubieran dejado a la Compañía un superávit nada

148 «Señores Diaristas», en Diario de Madrid, 18 de octubre de 1790 (núm. 291), pág. 1164.

149 «Fin de la Carta de ayer», op. cit., págs. 1167-1168. 
desdeñable de 21.488.000 reales. Obviamente el cálculo sólo era viable dando por asumido que la aseguradora llevaba veinte años de existencia, que durante esas dos décadas virtuales no habían acontecido desgracias mayores y dando por válidas estadísticas que eran meras hipótesis ${ }^{150}$.

Ahora bien, habida cuenta de las circunstancias, de la tremenda conmoción suscitada por la catástrofe, la demostración publicada en el Diario de Madrid, que pudo parecer a algunos estrafalaria pero se apoyaba en un riguroso cálculo de riesgos, debió hacer mella y aportar clientes a la aseguradora de la Corredora de San Pedro. El monarca desde luego aprobó sin el menor recelo la fundación de dicha compañía que, por lo que se refiere al ramo de los seguros terrestres, constituía en España toda una novedad. Pero el camino que quedaba por recorrer al respecto era inmenso.

Harto significativas son al respecto las reacciones que suscitó el proyecto presentado, años más tarde, ante el Gobernador del Consejo, por el Conde de Rofiñiaco. Este solicitó, el 24 de febrero de 1804, la autorización de crear una «Compañía de Afianzadores para la seguridad de las Casas de Madrid, conforme a lo que se observa[ba] en París y Londres» ${ }^{151}$. El 13 de abril el fiscal pidió el parecer del Ayuntamiento que, en 14 de mayo, remitió sus conclusiones, poco favorables habida cuenta de la escasez de los incendios y del recelo de los madrileños ante semejantes organismos. Y hubo que esperar tres años para que el fiscal se volviera a interesar por el asunto y encargara un nuevo informe, acudiendo esta vez a la Real Sociedad Económica Matritense ${ }^{152}$. En junta del 21 de marzo esta acordó trasmitir el expediente a Manuel de la Viña, miembro de la clase de industria $^{153}$. Poca confianza le inspiró el proyecto en el que veía

[...] aun suponiéndole dictado por el celo más puro, y más ardiente por el bien público [...], uno de aquellos planes quiméricos, y difíciles de realizarse, con los cuales más bien se logra arruinar, o a lo menos arriesgar los fondos públicos, y particulares, que conseguir el objeto deseado ${ }^{154}$.

Los establecimientos mercantiles, afirmaba, ofrecían inicialmente grandes ventajas. Para «estimular el interés público» prometían «ganancias exorbitantes»

$150 \quad$ Id.

151 AHn, Consejos, leg. 3274: Corte/1804. Expediente formado a representación del Conde de Rofiñiaco en que propone el establecimiento de una Compañia de Afianzadores para la seguridad de las Casas de Madrid, conforme a lo que se observa en París y Londres.

$152 I d$.

153 ARSEMAP, leg. 202-15.

154 Ibid., Informe de Manuel de la Viña, Madrid, 29 de julio de 1807, 5 págs. sin numerar. 
que les resultaba imposible perennizar. Y para cumplir con tamañas promesas, desplegaban enormes esfuerzos, muy superiores a sus fuerzas, lo que les impedía desarrollarse y propiciaba su decadencia. Tenemos, proseguía,

[...] un ejemplo de esta verdad en casi todos los Montepíos, Compañías de Comercio y otros establecimientos de esta clase que vemos en el día en la mayor inacción, entre los que principalmente podemos contar la Compañía de Seguros terrestres y marítimos [esa misma que se creó en 1790] fundada en esta Corte con el mismo objeto que el Señor Conde de Rofiñiaco quiere establecer la suya, y que a pesar de los privilegios y exenciones que debió a la munificencia de S. M. no ha prosperado, antes al contrario se halla casi enteramente arruinada ${ }^{155}$.

Asimismo tuvo a bien recalcar que Madrid, no era ni París, ni Londres:

Es un error muy grande [declaraba] el querer modelar los usos y establecimientos de un País por los de otro sin considerar la gran diferencia que puede haber en el espíritu público y en las circunstancias particulares de ambos. Madrid no se encuentra en el caso en que se halla Londres. En esta inmensa capital todo el mundo comercia. El continuo tráfico, el espíritu de especulación es el alma de sus habitantes. La imposibilidad en que se halla la policía de poder atender con toda eficacia al socorro de los incendios en una ciudad cuya extensión es tan grande hizo discurrir el establecimiento de una Compañía de afianzadores cuyo único objeto es la extinción de los incendios. La multitud de bombas destinadas a este objeto, de carros prontos a servirlas, de hombres señalados para jugarlas, los grandes premios que se dan a las primeras bombas que acuden al paraje incendiado, y otras providencias de esta clase de que se vale dicha compañía para apagar los fuegos, son unos medios de que puede valerse la policía de Madrid agregándolos a los que ya tiene, y que mejorados pueden ser suficientes a llenar este objeto respecto a su extensión, sin necesidad de apelar al establecimiento de una nueva Compañía, y cuando se creyera conveniente este medio, debiera con preferencia fomentarse la ya establecida removiendo los obstáculos que hubiesen impedido sus progresos ${ }^{156}$.

Los argumentos esgrimidos por Manuel de la Viña convencieron plenamente a los miembros de la Clase de Industria que juzgaron el proyecto del conde de Rofiñiaco inejecutable ${ }^{157}$. Tales fueron las tajantes conclusiones que, aprobadas en

\footnotetext{
$155 \quad I d$.

156 Id.

157 Ibid., Copia del Acta de la Clase de Industria de 27 de Agosto de 1807 que trata del Expediente del Conde de Rofiñiaco sobre establecer en Madrid una Compañía de afianzadores para los incendios, 2 págs.
} 
junta del 12 de septiembre, fueron transmitidas el 7 de octubre al Consejo. Con lo cual la compañía de afianzadores ideada por el Conde se quedó en agua de borrajas. Como recalcó atinadamente Manuel de la Viña, Madrid no era Londres.

\section{VI.2. Fomentar las medidas de prevención}

Indudablemente, pese al apoyo, muy circunstancial, prestado por el monarca a la compañía de terrestres y marítimos que se benefició de la fuerte conmoción suscitada por el incendio de la plaza Mayor, la prioridad del Gobierno, deseoso de que semejantes catástrofes no se volvieran a producir, iba a la prevención y a la modernización de los medios para combatir los incendios. Con ese fin el Consejo había ordenado el 26 de agosto la constitución de una Junta presidida por el conde de Campomanes y en la cual participarían Jerónimo Velarde y Sola (gobernador de la Sala), Miguel de Mendinueta y Muzquiz (ministro del Consejo), Francisco Antonio Elizondo (fiscal del Consejo y de la Cámara), Joseph Antonio de Armona (corregidor de Madrid), Joseph Joaquín Colón (alcalde de Casa y Corte), Manuel de Lardizábal (fiscal de la Sala), Martín Fajardo (regidor de Madrid), Alejandro Vallejo (procurador síndico general de la villa y caballero de la orden de Santiago), Juan de Villanueva (arquitecto mayor de Madrid) y Juan Dowling (ingeniero hidráulico por S. M. de las Fábricas del Reino) ${ }^{158}$. Al día siguiente, a las diez de la mañana se reunieron por primera vez en la posada de Campomanes con la firme intención de determinar por qué la Instrucción que manda el Consejo se observe para apagar y cortar los incendios que ocurran en Madrid recientemente publicada (el 20 de noviembre de 1789) ${ }^{159}$ no había surtido el efecto deseado y de abarcar todos los aspectos del problema. La Junta decidió se estableciera sin demora una «noticia puntual y exacta de las casas incendiadas y de las maltratadas para hacer cortes», «de todos los trabajadores, raciones y gastos» ocasionados, de las personas destinadas a apagar los incendios, de todos los útiles (y en particular de las bombas) en uso, precisando cuántos serían necesarios «para evitar la escasez que se ha[bía] notado». Pidieron a los regidores comisionados, al procurador síndico y al maestro mayor de Madrid informaran sobre los depósitos de agua y aljibes que había en la plaza Mayor y sobre el modo de abastecerles con «agua pura y sin corrupción», sin que fuera necesario valerse de las fuentes públicas. También optaron por pedir al corregidor, a los regidores cuarteleros, al procurador general y al maestro mayor el establecimiento de la lista de los maestros de obra, albañiles, peones y

158 AHN, Consejos, leg. 3274.

159 Instrucción que manda el Consejo se observe para apagar y cortar los incendios que ocurran en Madrid, en Madrid, en la Imprenta de don Pedro Marín, 1789, 19 págs. 
demás personas que por barrios habían de acudir «prontamente» a los incendios. Dowling presentó ese mismo día a los vocales un cubo de baqueta que mereció la aprobación de todos por ser «más útil y consistente que los de madera» que se solían usar y ocasionaban a menudo alguno que otro herido. Se trataba para mayor eficacia y de cara a nuevos incendios de analizar con el mayor rigor lo ocurrido, de establecer un estado riguroso de los medios humanos y materiales utilizables, sin omitir sacar el mayor provecho de las lecciones que podía brindarles el pasado. Con lo cual ordenaron a la par se investigara sobre los anteriores incendios de la plaza Mayor (los de 1631 y 1672) y el de Palacio, más reciente (1735). Asimismo Juan de Villanueva

[...] manifestó que consecuente al permiso que le había dado el Consejo, tenía en Borrador el dictamen sobre la nueva ordenanza de incendios que pondría en limpio y volvería luego, y se le encargó lo ejecutase con las observaciones que ha[bía] hecho de resultas del actual incendio, extendiendo además las reflexiones y noticias que ha[bía] dado a esta Junta en cuanto a los Maestros, Albañiles, Carpinteros de obras de fuera, y otros puntos conducentes a las personas y oficios a quienes se deb[ía] encargar el cuidado de la custodia y conservación de los utensilios de Fuegos, como sobre la construcción de los edificios para evitarlos en lo posible, y lo demás que t[uviese] por oportuno para la mayor instrucción de este asunto ${ }^{160}$.

Conforme a lo pedido el archivero de la Villa, Manuel Ramírez de Arellano, entregó el dos de septiembre de 1790 a Joseph Antonio de Armona un informe sobre los incendios de julio de 1631 y agosto de 1672 que incluía una relación de las medidas entonces adoptadas por las autoridades ${ }^{161}$. Y el 30 de octubre la junta, para tratar del modo y medio de apagar los fuegos de Madrid, tenía entre sus manos un voluminoso expediente en que Villanueva exponía con la mayor claridad el resultado de sus reflexiones sobre el tema ${ }^{162}$. El maestro mayor de la Ciudad no disimulaba la necesidad de reformar el método de construcción de los edificios, limitando el recurso a la madera en beneficio de «materiales no tan combustibles». Pero en espera de ello, convenía centrarse en la manera de luchar eficazmente contra los incendios. Varias providencias, atinadas, ya se habían

\footnotetext{
160 AHN, Consejos, leg. 3274. Resoluciones de la Junta del 27 de agosto de 1790.

161 AHn, Consejos, leg. 3274. Informe establecido por Manuel Ramírez de Arellano, del gremio de la Universidad de Salamanca y Archivero de la Villa, Madrid, 2 de septiembre de 1790, ff. 73-81.

162 AHN, Consejos, leg. 3274. Junta para tratar del modo y medio de apagar los fuegos en Madrid. Papeles entregados por el Arquitecto Maestro mayor de Madrid, al Secretario de S. M. y de Gobierno del Consejo don Pedro Escolano de Arrieta en la Junta que se celebró en la Posada del Excmo. Señor Conde de Campomanes Gobernador del Consejo el día 30 de octubre de 1790 para tratar de los medios de apagar los incendios, ff. 9-35. El expediente consta de varias piezas fechadas entre el 25 de agosto y el 12 de octubre de 1790.
} 
tomado al respecto pero estas, subrayaba, ni eran suficientes, ni se cumplían con «la exactitud y celo» requeridos. A su juicio, convenía ante todo que el gobierno fijara reglas estrictas para combatir «la tropelía, confusión y desarreglo» que se desataban nada más declararse un incendio:

Todos [lamentaba] quieren apagar, todos huir, y todos recoger sus más cortos bienes. La concurrencia de los auxiliadores va por lo regular disfrazada con varias máscaras, la caridad, la intrepidez, celo, actividad, curiosidad, interés y rapiña; se confunden entre sí y obran bajo el aparente amor al prójimo ${ }^{163}$.

Para evitar semejante confusión y que se tomasen las medidas más adaptadas, convenía a su juicio confiar la dirección de las operaciones a una sola y única persona, la más capacitada para analizar la situación, o sea el maestro mayor, cuando la ordenanza de 1789 especificaba que tal cometido incumbía al alcalde de Corte, al teniente, o al regidor de la villa ${ }^{164}$. Y afirmaba:

Sólo la ciencia y el saber de un Profesor Arquitecto puede conocer la calidad, extensión y resultas del daño, y medios de atajarlo y remediarlo. ¿Por qué han de mandar todos, a todos se ha de oír, e individualmente todos han de obrar? ¿Son acaso todos los brazos a propósito? ¿Los conocimientos particulares de un Arte, y su práctica, pueden ser tan generalmente adquiridos? ¿Puede ser suficiente una ligera instrucción para conocer los muchos medios que el uso y ejecución enseña al Profesor experimentado? No lo creo. ¿Luego, por qué no dejar a su elección los brazos, y medios que conozca poderosos y eficaces? ${ }^{\text {165 }}$.

También insistía en la necesidad, para mayor eficacia, de limitar el número de operarios, acudiendo de ser posible exclusivamente a la tropa y a obreros especializados en el manejo de los útiles necesarios para combatir el fuego, proceder a los cortes y al desbroce. "Las sobradas manos que sin conocimiento se arrojan a obrar en los trabajos» llevadas por «la curiosidad, o tal vez un buen deseo» habían

163 Ibid., pieza núm. 1, 26 de agosto de 1790, f. 10.

164 Instrucción que manda el Consejo se observe para apagar y cortar los incendios que ocurran en Madrid, op. cit., págs. 3-4, artículos V y VI: «V. Será preventiva la asistencia de los alcaldes de Corte, tenientes de villa y regidores cuarteleros, y el primero que llegare empezará a tomar las providencias oportunas a cortar el fuego, procurando avistarse los que llegaren después, para proceder de acuerdo, en la inteligencia de que todos han de conspirar a remediar la desgracia. / VI. En el concurso de alcalde de Corte, teniente o regidor de villa, ha de tomar el mando el primero en todo lo perteneciente a la ejecución del trabajo para apagar el fuego, poner en salvo las personas, y asegurar los muebles, auxiliando sus providencias el teniente y regidores».

165 AHN, Consejos, leg. 3274. Junta para tratar del modo y medio de apagar los fuegos en Madrid. Papeles entregados por el Arquitecto Maestro mayor de Madrid, op. cit., pieza 1, f. 11. 
de ser apartadas estableciendo cordones de ministros y tropa ${ }^{166}$. Múltiples eran las reformas que convenía aportar para aminorar los riesgos y combatir eficazmente el fuego y para ello, cercioraba, convenía establecer una Instrucción gubernativa de la concurrencia a la operación de atajar los incendios ya que «las demasiadas reglas, y ordenanzas que quieren prescribir menudamente el por menor más sirven de embarazo, que de instrucción, y las más veces producen tan sólo dudas y hacen perder el tiempo útil y preciso en tales acontecimientos» ${ }^{167}$. Partiendo de esos principios básicos hizo varias propuestas concretas relativas al nombramiento de profesores para la asistencia a los incendios, a la creación de una maestranza de albañilería y carpintería para ejecutar los cortes, la formación de la matrícula de carpinteros y albañiles matafuegos ${ }^{168}$, el papel fundamental de los arquitectos, los cuerpos que habían de intervenir en las operaciones, el material necesario ${ }^{169}$, la ocupación de los alcaldes y el funcionamiento de sus rondas ${ }^{170}$, los cargos de Madrid ${ }^{171}$ o las normas de construcción y aprovisionamiento de los aljibes $^{172}$. Pero de poco sirvieron las recomendaciones de Villanueva.

El 8 de noviembre de de 1790 se publicó, en espera de una «completa ordenanza», un bando en el cual se daban a conocer varias medidas destinadas a limitar al máximo los riesgos de incendio, erradicando ciertos hábitos dañosos ${ }^{173}$. El primer artículo (sobre un total de 19) especificaba que los fogones, hornos y chimeneas habrían de construirse en lo sucesivo «con solidez, sin madera alguna, quedando los maestros responsables a cualquiera desgracia que suced[iera] por su impericia o descuido». Se exigía de los dueños que hicieran limpiar a su coste las chimeneas una vez al año (en cuanto a casas particulares) y cada cuatro meses si estaban destinadas a un uso laboral (art. IV). Se estipuló que las materias combustibles, como el alquitrán, la pez, la resina o las gomas sólo las podrían vender los drogueros con tal que las conservaran en sótanos o cuevas embovedadas y en cantidades limitadas (art. V), que los carpinteros, tallistas y ebanistas habían de almacenar las maderas en corrales que no podrían visitar de noche sino con farol de vidrio (art. VII). Se renovó «la prohibición de fuegos artificiales de cohetes, tiros de fusil o pistola, incluyéndose en aquellos los que

\footnotetext{
166 Ibid., f. 12.

167 Id.

168 Ibid., pieza 2, informe del 12 de octubre, ff. 14-18.

169 Ibid., pieza 3, informe del 20 de agosto de 1790, ff. 19-24.

$170 \quad$ Ibid., pieza 4, informe del 12 de octubre, ff. 25-27.

171 Ibid., pieza 4, informe del 12 de octubre de 1790, ff. 28-29.

172 Ibid., pieza 5, informe del 12 de octubre de 1790, ff. 30-32.

173 Dicho bando difundido mediante carteles fijados en los «parajes acostumbrados» y por vía de prensa se publicó en el Diario de Madrid del 9 de noviembre de 1790 (núm. 313), págs. 1255-1258, y posteriormente en el Memorial literario, diciembre de 1790 (parte I), págs. 481-488.
} 
suelen tirar los muchachos en las calles y paseos, por diversión» so pena de una multa de diez ducados exigida a los padres (art. VIII). Se prohibió «absolutamente el uso de las luminarias de tea o virutas de madera, que se acostumbran poner delante de las Iglesias la víspera de sus fiestas» (art. XI). Se precisó que «no se podr[ían] encender ni sacar braseros, ni otra vasija con lumbre a los balcones en la plaza, ni en sus manzanas, ni arrojar cenizas por dichos balcones» (art. XVII). Se dio a conocer que serían castigados con el mayor rigor «los que en los incendios arroja[sen] trastos, de cualquier calidad que [fueran], por las ventanas en perjuicio de sus dueños, y con inminente riesgo de los que están en la calle no siendo afianzados dichos trastos por maromas» o las personas que no dieran inmediatamente la alerta en caso de incendio (art. XVIII). Cada infracción daría lugar a una multa dedicándose dos tercios de su importe al «fondo de incendios» y uno a los delatores y ministros de justicia. Asimismo, en 1791 el Consejo de Castilla, siguiendo las propuestas de Villanueva y de Sabatini, dio una Instrucción sobre «las reglas que deben observarse para la reedificación de las casas arruinadas en la plaza Mayor» ${ }^{174}$.

El drama de la plaza Mayor fue pues el punto de partida de una amplia reflexión sobre el modo de prevenir y extinguir los incendios. Durante más de dos años se aunaron informaciones, se multiplicaron los informes, los memoriales, se amontonaron las propuestas. De todo ello resultó un voluminoso expediente que se transmitió a la Sala el 13 de octubre de 1792 y sobre el cual el Fiscal dictaminó tan sólo el 24 de marzo de 1803, pero sin que por ello se pasase de la teoría a la práctica.

\section{Una conclusión tardía}

Como era de esperar todo quedó en agua de borrajas y no se volvió a consultar el polvoriento expediente hasta enero de 1816, fecha en que Madrid acababa de padecer un nuevo incendio, esta vez en la Puerta del Sol. Saltaba a la vista que poco o nada había cambiado desde 1790. Los miembros de la Sala de Corte no lo negaron. Pero corrieron un tupido velo sobre la patente ineficacia de las autoridades y no resistieron la tentación de culpar a José I que, como bien se sabe, tan sólo ciñó la corona española en 1808. Así el 30 de enero de 1816 declaraban:

$174 \quad$ Instrucción dispuesta de orden del Consejo, y aprobada por S. M. de las reglas que deben observarse para la reedificación de las casas arruinadas en la plaza Mayor, con motivo del incendio ocurrido la noche del día diez y seis de Agosto de mil novecientos y noventa, 5 de julio de 1791, 11 págs. Vid. al respecto María de los Santos García Felguera, «El incendio de la plaza Mayor de Madrid en 1790 y los sistemas de construcción en la ciudad», en Anales del Instituto de Estudios Madrileños, Madrid, CSIc, 1982, tomo XIX, págs. 485-499. 
Desde entonces [1803] puede decirse con verdad que el Expediente ha quedado sin curso alguno, y si al tiempo que ha transcurrido se considera la desgraciada época que se subsiguió e hizo sucumbir a esta capital el yugo del Tirano usurpador y la extinción de la misma Sala de Corte, se puede creer con fundamento que habían para siempre quedado sepultados en el olvido tan excelentes ideas y proyectos como tiene, y la colección de los mejores reglamentos de la Europa en materia de incendios, si el desgraciado y ominoso suceso de la Puerta del Sol no hubiese vuelto a recordar la absoluta necesidad que hay de arreglar este interesante ramo de la policía, acaso el primero y más esencial en una Corte, y especialmente en la nuestra, por la reunión del mucho vecindario en poco terreno, y la construcción de sus edificios ${ }^{175}$.

Para solventar el problema el Fiscal pidió el 12 de marzo del mismo año que se crease una nueva Junta «como la que se mandó formar en la Posada del Gobernador del Consejo en 26 de Agosto de 1790» ${ }^{176}$. Y así se hizo, llegándose, el 23 de diciembre de 1819, a la magnífica conclusión de que la Instrucción de 1789 era inmejorable con tal que se aplicase. Esa misma Instrucción que según Villanueva convenía reformar pero que se había reeditado sin la menor modificación en 1808. Con lo cual el Fiscal en su informe exigió la mayor «energía en la ejecución de aquellas providencias, pues de nada sirven las mejores leyes, si las personas a quienes se les confían, lejos de llevarlas a efecto son apáticas, descuidadas u omisas» ${ }^{177}$. El incendio de la plaza Mayor de Madrid de agosto de 1790 y el tratamiento a que dio lugar demostraban una vez más que en la España de aquel entonces la ley se acataba, pero no se cumplía y cuán difícil era el paso de la teoría a la práctica. Una vez más quedaban patentes los límites de la Ilustración que no supo sacar del espectacular incendio de 1790 las lecciones que se imponían. Pero de esto los Napoleones no tenían la culpa.

\footnotetext{
175 AHN, Consejos, leg. 3274, Sala plena de Corte, Madrid, 30 de diciembre de 1816, 5 págs. sin numerar.

176 Ibid., Resolución del fiscal, 12 de marzo de 1816: «El Fiscal halla muy justificados los motivos que excitan el celo de la Sala, y muy digna de observarse la Instrucción del Consejo de 20 de Noviembre de 1789 sobre incendios de la Corte; para cuyo fin entiende que será muy del caso el restablecimiento de una Junta como la que se mandó formar en la Posada del Gobernador del Consejo en 26 de Agosto de 1790; la cual podrá activar el más puntual cumplimiento de que se previno en dicha Instrucción, allanando las dificultades que se opongan para realizarlo, teniendo presente lo representado por la misma Sala en 19 de Agosto del mismo año, y lo que ahora expone con respecto a la falta de útiles herramientas y demás auxilios de cargo de la Villa con todo lo demás que resulta de este expediente sobre el cual acordará no obstante el Consejo lo que entendiere más conforme».

177 Ibid., Informe del Fiscal, Madrid, 23 de diciembre de 1819.
} 